MARIANA SPONCHIADO

O ambiente endócrino periovulatório modula a expressão gênica e o funcionamento do endométrio no início do ciclo estral em bovinos

Pirassununga

2015 


\section{O ambiente endócrino periovulatório modula a expressão gênica e o funcionamento do endométrio no início do ciclo estral em bovinos}

Dissertação apresentada ao Programa de PósGraduação em Reprodução Animal da Faculdade de Medicina Veterinária e Zootecnia da Universidade de São Paulo para a obtenção do título de Mestre em Ciências

\section{Departamento:}

Reprodução Animal

Área de concentração:

Reprodução Animal

Orientador:

Prof. Dr. Mário Binelli

Pirassununga 
Autorizo a reprodução parcial ou total desta obra, para fins acadêmicos, desde que citada a fonte.

\section{DADOS INTERNACIONAIS DE CATALOGAÇÃO-NA-PUBLICAÇÃO}

(Biblioteca Virginie Buff D’Ápice da Faculdade de Medicina Veterinária e Zootecnia da Universidade de São Paulo)

Sponchiado, Mariana

O ambiente endócrino periovulatório modula a expressão gênica e o funcionamento do endométrio no início do ciclo estral em bovinos / Mariana Sponchiado. -- 2015.

69 f. : il.

Dissertação (Mestrado) - Universidade de São Paulo. Faculdade de Medicina Veterinária e Zootecnia. Departamento de Reprodução Animal, Pirassununga, 2015.

Programa de Pós-Graduação: Reprodução Animal.

Área de concentração: Reprodução Animal.

Orientador: Prof. Dr. Mário Binelli.

1. Útero. 2. Receptividade. 3. Esteroides sexuais. 4. Vacas Nelore. I. Título. 
UNIVERSIDADE DE SÃO PAULO

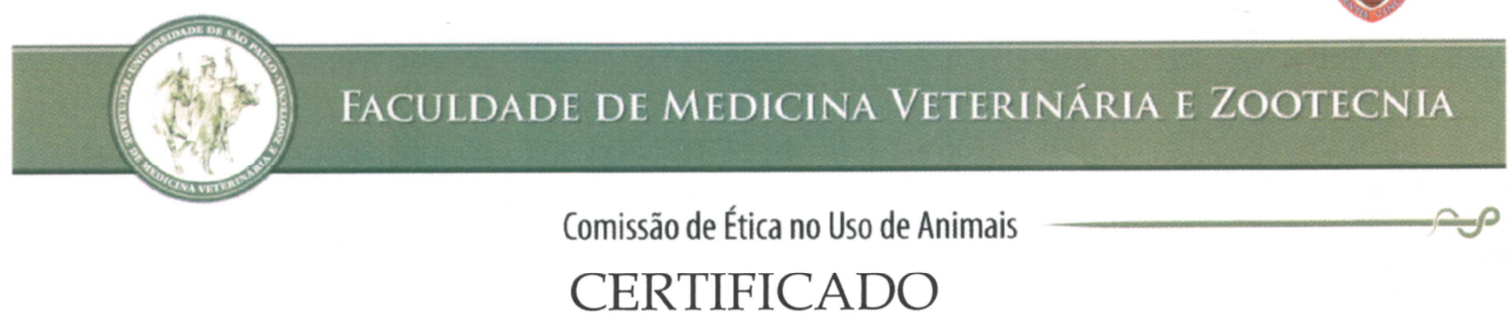

Certificamos que o Projeto intitulado "Efeito do ambiente endócrino periovulatório na expressão gênica do endométrio durante a primeira semana do ciclo estral em bovinos: expressão de receptores de estradiol e seus genes alvo", protocolado sob o $\mathrm{n}^{\mathrm{o}} 3125 / 2013$, utilizando 80 (oitenta) bovinos, sob a responsabilidade do(a) Prof. Dr. Mário Binelli, foi aprovado em reunião de 14/8/2013 e está de acordo com os princípios éticos de experimentação animal da Comissão de Ética no Uso de Animais da Faculdade de Medicina Veterinária e Zootecnia da Universidade de São Paulo.

We certify that the Research "Effect of the periovulatory endocrine milieu on endometrial gene and protein expression during the first week post-estrus in cattle: estradiol receptors expression and their target genes", protocol number $3125 / 2013$, utilizing 80 (eighty) cattle, under the responsibility Prof. Dr. Mário Binelli, was approved in the meeting of day 8/14/2013 and agree with Ethical Principles in Animal Research adopted by Ethic Committee in the Use of Animals of the School of Veterinary Medicine and Animal Science of University of São Paulo.

São Paulo, 14 de agosto de 2013.

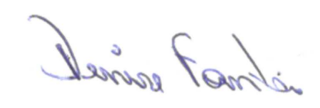

Denise Tabacchi Fantoni

Presidente 
Autor: SPONCHIADO, Mariana

Título: 0 ambiente endócrino periovulatório modula a expressão gênica e o funcionamento do endométrio no início do ciclo estral em bovinos

Dissertação apresentada ao Programa de Pós-Graduação em Reprodução Animal da Faculdade de Medicina Veterinária e Zootecnia da Universidade de São Paulo para obtenção do título de Mestre em Ciências

Data:

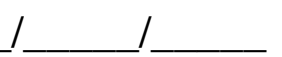

\section{Banca Examinadora}

Prof. Dr.

Instituição: Julgamento:

Prof. Dr.

Instituição: Julgamento:

Prof. Dr. Instituição: Julgamento: 


\section{DEDICATÓRIA}

A meus pais,

Que não tenha passado um momento, sem que eu pensasse em vocês. 


\section{AGRADECIMENTOS}

A meus pais, Benhur e Rosi Sponchiado, primeiros exemplos e incentivadores das minhas escolhas. A meus irmãos, Julhana e Mateus, pelo carinho. Obrigada pela compreensão e pelos olhares atenciosos que jamais falharam.

Aos demais familiares que sempre se mostraram presentes, incentivando e confortando meus passos.

Ao Prof. Dr. Mário Binelli por ter me acolhido em seu grupo de pesquisa, pelo exemplo de dedicação à ciência, pela orientação e irrestrita ajuda na conclusão deste trabalho.

Ao Dr. Guilherme Pugliesi e Dra. Veerle van Hoeck por contribuírem grandemente com o trabalho. Ao Prof. Dr. Fernando Mesquita e Profa. Dra. Cláudia Maria Bertan Membrive pela ajuda no delineamento experimental, coleta de amostras e desenvolvimento de todo o modelo animal. Também, aos colegas do Laboratório de Fisiologia e Endocrinologia Molecular, por desenvolverem a primeira parte do projeto.

À Universidade de São Paulo, Faculdade de Medicina Veterinária e Zootecnia e ao Departamento de Reprodução Animal, por tornarem possível a execução dos experimentos, desde o alojamento dos animais, até as últimas análises. Às agências de fomento, FAPESP, CAPES e CNPq, pelo aporte financeiro.

Ao Prof. Dr. Guilherme Nogueira e Prof. Dr. Marcelo Nogueira e demais membros da banca por terem aceitado analisar este trabalho e contribuírem com correções, críticas e sugestões.

Aos professores, funcionários e colegas do Departamento de Reprodução Animal.

À Universidade do Estado de Santa Catarina, pela formação acadêmica. À toda equipe do Laboratório de Reprodução Animal Prof. Assis Roberto de Bem pela oportunidade de estágio durante a graduação. Em especial, ao Prof. Dr. Alceu Mezzalira, por compartilhar suas experiências e pelo comprometimento com a formação pessoal e científica de seus alunos.

Ao Thiago, pelo companheirismo e equilíbrio nesses momentos finais. Aos meus amigos, com os quais também dividi as angústias e dificuldades durante esses anos, agora compartilho esse momento especial e de grande alegria. 


\section{RESUMO}

SPONCHIADO, M. O ambiente endócrino periovulatório modula a expressão gênica e o funcionamento do endométrio no início do ciclo estral em bovinos. [Periovulatory sex steroid tone controls transcription and function of the bovine uterus]. 2015. 69 f. Dissertação (Mestrado em Ciências) - Faculdade de Medicina Veterinária e Zootecnia, Universidade de São Paulo, Pirassununga, 2015.

O estabelecimento gestacional é determinado por interações entre o perfil endócrino e o trato reprodutivo materno. Eventos endócrinos são primariamente mediados pela ligação do hormônio a receptores específicos e subsequente transcrição de genes alvos. O endométrio bovino é um tecido dinâmico que passa por alterações espaçotemporais dirigidas pelos hormônios ovarianos, estradiol (E2) e progesterona (P4). A hipótese é que os efeitos combinados das concentrações plasmáticas de E2 e P4 à abundância tecidual de seus respectivos receptores estabelecem um "tônus de esteroides sexuais" que dirige funções do endométrio durante o período periovulatório em vacas. Os objetivos foram comparar diferentes tônus de esteroides na (1) expressão de receptores específicos e sua distribuição tecidual, (2) expressão de genes de resposta que regulam a função uterina, e (3) abundância e distribuição de mucina pelo epitélio, uma glicoproteína que indica pobre receptividade endometrial. Vacas Nelore (Bos indicus) foram farmacologicamente manipuladas para ovular um folículo pequeno (FP-CLP) ou grande (FG-CLG) e produzir, respectivamente, menores ou maiores concentrações plasmáticas de E2 no proestro e de P4 no diestro. O grupo FG-CLG representa um modelo de maior fertilidade. Tecido endometrial foi coletado através de biópsia transvaginal no dia zero (D0; FPCLP, $n=4 ; F G-C L G, n=5$ ) e post mortem no D4 ( $n=8$ por grupo; Experimento 1) ou D7 (FP-CLP, n=8; FG-CLG, n=9; Experimento 2) após indução da ovulação com GnRH. Para estudar a regulação endometrial dos receptores de esteroides, a abundância de transcritos para receptores nucleares e de membrana de esteroides foi mesurada por qPCR: receptor de estrógenos alpha (ESR1) e beta (ESR2), receptor de estrógeno acoplado a proteína $\mathrm{G}(G P E R)$, receptor de $\mathrm{P} 4$ isoformas $\mathrm{A}$ (PGR1), B (PGR2) e C (PGR3), receptor de P4 componente de membrana 1 (PGRMC1) e 2 (PGRMC2). Genes previamente mostrados estarem envolvidos em vias de resposta ao E2 foram selecionados: GREB1, CCND1, WNT5a, FGF2 
(proliferação), SERPINA14, LTF, NRIP1 (atividade secretória), MMP2 (remodelamento de matriz extracelular), AQP4 (transporte de água) e MUC1 (adesão celular). Os dados foram analisados por one-way ANOVA para efeito de tratamento. $\mathrm{O}$ tamanho do $\mathrm{POF}$, subsequente $\mathrm{CL}$, concentrações plasmáticas de $\mathrm{E} 2$ (D0) e P4 (D4 e D7) foram significativamente maiores no grupo FG-CLG. No D0, a abundância de mRNA para ESR1, PGR1, PGR2 e PGR3 foi significativamente maior no tecido endometrial de vacas do grupo FG-CLG. A abundância de transcritos envolvidos na proliferação e remodelamento de matriz extracelular sugeriu maior atividade proliferativa e remodelamento no endométrio do grupo FG-CLG no D0. No D4, a expressão de PGR1 e PGRMC2 foi menor no grupo FG-CLG. A abundância de mRNA para $A Q P 4$ foi maior no grupo FG-CLG e positivamente correlacionada com a concentração de E2 pré-ovulatório. No D7, a abundância de mRNA foi maior para ESR2, PGRMC1 e PGRMC2, e reduzida para PGR2 e PGR3 em vacas do grupo FG-CLG. Abundância de mRNA para OXTR e MUC1 foi menor neste grupo. Análise histológica de amostras endometriais revelaram que o sinal para mucinas anti-adesivas no epitélio do grupo FG-CLG foi consistentemente menor quando comparado ao grupo FP-CLP $(33.3 \%$ vs. $62.0 \%)$ no D7. A menor expressão de mucinas transmembranas indica a condição receptiva do endométrio. Estes resultados confirmam que a complexa modulação da expressão dos receptores de esteroides pelo ambiente endócrino periovulatório altera a transcrição de genes alvos de maneira tempo-específica para regular a receptividade uterina ao embrião em desenvolvimento.

Palavras-chave: Útero. Receptividade. Esteroides sexuais. Vacas Nelore. 


\begin{abstract}
SPONCHIADO, M. Periovulatory sex steroid tone controls transcription and function of the bovine uterus. [O ambiente endócrino periovulatório modula $a$ expressão gênica e o funcionamento do endométrio no início do ciclo estral em bovinos]. 2015. 69 f. Dissertação (Mestrado em Ciências) - Faculdade de Medicina Veterinária e Zootecnia, Universidade de São Paulo, Pirassununga, 2015.
\end{abstract}

Establishment of pregnancy depends on a well-balanced interplay between the endocrine profiles and the maternal reproductive tract. Endocrine actions are primarily mediated by binding to specific receptors and subsequent transcription of responsive genes. The bovine endometrium is a dynamic tissue that undergoes spatiotemporal functional changes directed by ovarian hormones, estradiol (E2) and progesterone (P4). Hypothesis is that the combined effects of plasma concentrations of E2 and P4 and tissue abundance of their respective receptors establish a "sex steroid tone" that directs endometrial function during the periovulatory period in cattle. Therefore, the aims were to compare different sex steroid tones on (1) steroid receptors gene expression and protein distribution, (2) expression of steroid responsive genes that regulate uterine function and (3) abundance and distribution of epithelial mucin, a glycoprotein that indicates poor endometrial receptivity. Nelore (Bos indicus) cows were pharmacologically manipulated to ovulate small (SF-SCL) or large (LF-LCL) follicles. Consequently, LF-LCL group was associated with greater proestrus concentrations of E2 and diestrus concentrations of P4, which were previously associated with greater receptivity and fertility. Endometrial tissue was collected by transvaginal biopsy on day zero (D0; SF-SCL, $n=4 ; L F-L C L, n=5$ ), and post mortem on D4 ( $\mathrm{n}=8$ per group; Experiment 1) or D7 (SF-SCL, $n=8$; LF-LCL, $n=9$; Experiment 2) after $\mathrm{GnRH}$-induced ovulation. To study the regulation of endometrial steroid receptors, abundance of the following transcripts for nuclear and membrane receptor for steroids was measure by $\mathrm{qPCR}$ : estrogen receptor alpha (ESR1) and beta (ESR2), G protein-coupled estrogen receptor (GPER), progesterone receptor isoforms $\mathrm{A}(P G R 1), \mathrm{B}(P G R 2)$ and $\mathrm{C}(P G R 3)$, progesterone receptor membrane component 1 (PGRMC1) and 2 (PGRMC2). A subset of genes previously shown to be involved with estrogen-dependent pathways was also studied: GREB1, CCND1, WNT5a, FGF2 (proliferation), SERPINA14, LTF, NRIP1 (secretory activity), MMP2 
(extracellular matrix remodeling), AQP4 (aqueous transport) and MUC1 (celladhesion pathways). Data were analyzed by one-way ANOVA for the effect of treatment. The POF, subsequent CL size, plasmatic E2 (D0) and P4 concentrations (D4 and D7) were significantly greater in the LF-LCL group. On D0, the abundance of mRNA for ESR1, PGR1, PGR2 and PGR3 genes was significantly up-regulated in the endometrial tissue from LF-LCL cows compared to the SF-SCL counterparts. Abundance of transcripts for growth-related and extracellular matrix remodelingrelated genes suggested greater proliferative and remodeling activity on LF-LCL than SF-SCL endometrial tissue at D0. On D4, expression of PGR1 and PGRMC2 was down-regulated in the LF-LCL group. The AQP4 mRNA abundance was greater in LF-LCL group and it was positively correlated with preovulatory E2 concentration. On D7, mRNA abundance was greater for ESR2, PGRMC1 and PGRMC2, while it was reduced for $P G R 2$ and $P G R 3$ in the LF-LCL cows. Abundance of mRNA for secretory activity-related genes was increased in LF-LCL group. Abundance of mRNA for OXTR and MUC1 was down-regulated in the LF-LCL group. Histology of endometrial samples revealed that the signal for anti-adhesive mucin at the LF-LCL epithelium was consistently lower than that of the SF-SCL tissue (33.3\% vs. $62.0 \%)$ at D7. A down-regulated expression of the transmembrane mucin indicates a receptive condition of the endometrium. These results confirm that complex modulation of receptor expression by the periovulatory steroid milieu alters transcription of responsive genes in a time-specific manner to regulate uterine receptivity to the developing embryo.

Keywords: Endometrium. Receptivity. Steroid receptors. Nelore cows. 


\section{LISTA DE FIGURAS}

Figure 1 -- Mechanisms of gene regulation in response to estrogen in target cells. Classical mechanism ligand-dependent: Estrogen (E), due to its lipophilic properties, (1) can enter cells through the membrane and interact with the nuclear estrogen receptor (ER). ERs are transcription factors that are specifically activated by estrogens. (2) Once the agonist binds to the ER, several events occur, including conformational changes, dissociation from chaperones proteins such as hsp90, (3) translocate to the nucleus and dimerizes, exposure of zinc fingers, and recruitment of accessory proteins. In the classical mechanism, (4) the transcriptionally active estrogenER complex bind to the estrogen-responsive elements (ERE) present in the promoter region of target genes (KLEIN-HITPASS et al., 1988). DNA-bound receptors alter rates of transcription of responsive genes through recruitment of coactivator or corepressor proteins. Finally, RNA polymerase II and the general transcription machinery assemble at the promoter and the gene is transcribe. (5) The tissue response is manifested as an alteration in cellular phenotype due regulation of responsive genes and protein synthesis. Cell-surface (nongenomic) signaling: (6) E activates a putative membrane-associated binding site (GPER) linked to intracellular signal transduction pathways that generate rapid estrogen responses

Figure 2 - Schematic representation summarizing the experimental model to generate two groups of cows, presenting a large (LF-LCL) or small (SF-SCL) preovulatory follicle and subsequent corpus luteum

Figure 3 - Abundance of mRNA for steroid receptors normalized to cyclophilin A $(P P I A), \beta$-Actin $(A C T B)$, ribosomal protein S18 (RPS18) and glyceraldehyde-3-phosphate dehydrogenase $(G A P D H)$ in endometrium from beef cows synchronized to ovulate a large (LFLCL) or small follicle (SF-SCL) on day of GnRH treatment (D0), four (D4) or seven (D7) days later. Significant differences $(P<0.05)$ between treatments is indicated. Genes: estrogen receptor $\alpha$ (ESR1), estrogen receptor $\beta$ (ESR2), G protein-coupled estrogen receptor (GPER), progesterone receptor isoform A (PGR1), isoform $(P G R 2)$ and isoform $\mathrm{C}(P G R 3)$, progesterone receptor membrane component 1 (PGRMC1) and 2 (PGRMC2)

Figure 4 - Abundance of mRNA for estrogen responsive genes normalized to cyclophilin A $(P P I A)$, $\beta$-Actin $(A C T B)$, ribosomal protein $\mathrm{S18}$ (RPS18) and glyceraldehyde-3-phosphate dehydrogenase $(G A P D H)$ in endometrium from beef cows synchronized to ovulate a large (LF-LCL) or small follicle (SF-SCL) on day of GnRH treatment (D0), four (D4) or seven (D7) days later. Significant differences $(P<0.05)$ between treatments is indicated. Genes: growth regulation by estrogen in breast cancer 1 (GREB1); cyclin D1 (CCND1); 
wingless-type MMTV integration site family, member 5A (WNT5A); fibroblast growth factor 2 (FGF2); matrix metallopeptidase 2 (MMP2) and nuclear receptor interacting protein 1 (NRIP1)

Figure 5 - Abundance of mRNA for estrogen responsive genes normalized to cyclophilin A (PPIA), $\beta$-Actin (ACTB), ribosomal protein $\mathrm{S} 18$ (RPS18) and glyceraldehyde-3-phosphate dehydrogenase (GAPDH) in endometrium from beef cows synchronized to ovulate a large (LF-LCL) or small follicle (SF-SCL) on day of GnRH treatment (D0), four (D4) or seven (D7) days later. Significant differences $(P<0.05)$ between treatments is indicated. Genes: aquaporin 4 (AQP4); lactotransferrin (LTF); serpin peptidase inhibitor, clade $\mathrm{A}$ member 14 (SERPINA14), mucin 1 cell surface associated (MUC1) and oxytocin receptor $(O X T R)$.

Figure 6 - Localization of nuclear estrogen receptor alpha (ER $\alpha)$ in bovine endometrium collected on D4 (Experiment 1; SF-SCL panel A, LFLCL panel B) and D7 (Experiment 2; SF-SCL panel C, LF-LCL panel D) of cows with larger (LF-LCL group) or smaller (SF-SCL) pre-ovulatory follicle and corpus luteum. No immunopositive staining was detected when primary antibody was replaced by mouse IgG (Negative control, panel E and F). Representative images of PGR protein immunolocalization in luminal epithelium (LE), glandular epithelium (GE), and stroma cells (SC). Original magnification $200 x$

Figure 7 - Localization of nuclear progesterone receptor (PGR) in bovine endometrium collected on D4 (Experiment 1; SF-SCL panel A, LFLCL panel B) and D7 (Experiment 2; SF-SCL panel C, LF-LCL panel D) of cows with larger (LF-LCL group) or smaller (SF-SCL) pre-ovulatory follicle and corpus luteum. No immunopositive staining was detected when primary antibody was replaced by mouse IgG (Negative control, panel E and F). Representative images of PGR protein immunolocalization in luminal epithelium (LE), glandular epithelium (GE), and stroma cells (SC). Original magnification $200 x$

Figure 8 - Visualization of sulfated and carboxylated acid mucopolysaccharides and sulfated and carboxylated sialomucins in bovine endometrium collected on D7 (Experiment 2) using Alcian Blue Stain. Duodenal sections were used as positive (Panel E) control. Representative images of mucins staining in glandular epithelium (GE; Panel $A$ and $B$ ) and luminal epithelium (LE, Panel C and D) in the SF-SCL (Panel A and C) and LF-LCL (Panel B and D) groups. Original magnification $400 x$ 


\section{LISTA DE TABELAS}

Table 1 - Primer sequences of target and reference genes analyzed by qPCR

Table 2 - Pre-ovulatory follicle (POF), corpus luteum (CL), estradiol concentration (E2) and progesterone concentration (P4) measurements in cows with smaller POF and $\mathrm{CL}$ (SF-SCL) or lager $\mathrm{POF}$ and $\mathrm{CL}(\mathrm{LF}-\mathrm{LCL})$ in Experiment 1. Values are expressed as means \pm SEM.

Table 3 - Pre-ovulatory follicle (POF), corpus luteum (CL), estradiol concentration (E2) and progesterone concentration (P4) measurements in cows with smaller POF and $\mathrm{CL}$ (SF-SCL) or lager POF and $\mathrm{CL}$ (LF-LCL) in Experiment 2. Values are expressed as means \pm SEM. 


\section{SUMÁRIO}

1 INTRODUÇÃO GERAL

2 CHAPTER 1: LITERATURE REVIEW

2.1 STEROID RECEPTORS: RELATIONSHIP BETWEEN HORMONAL TONE AND TISSUE

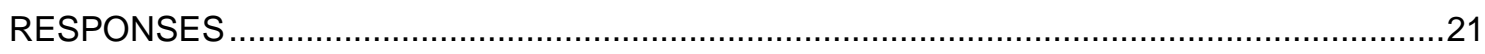

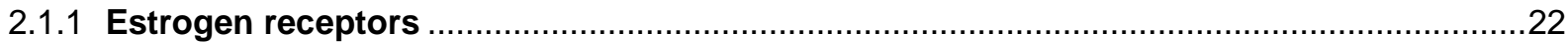

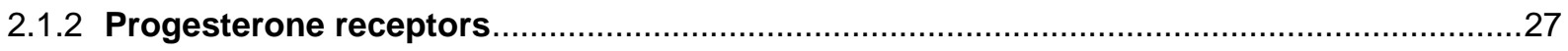

2.2 REGULATION OF STEROID RECEPTORS IN THE ENDOMETRIUM ..................................28

3 CHAPTER 2: PERIOVULATORY SEX STEROID TONE CONTROLS TRANSCRIPTION AND FUNCTION OF THE BOVINE UTERUS ..........................................30

3.1 INTRODUCTION 30

3.2 MATERIAL AND METHODS

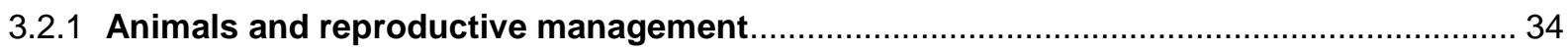

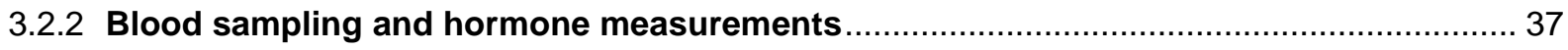

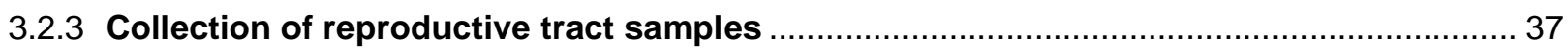

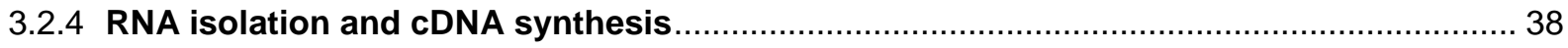

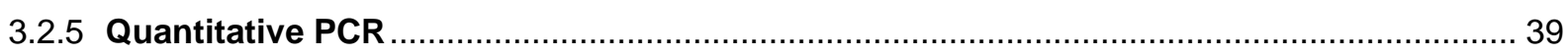

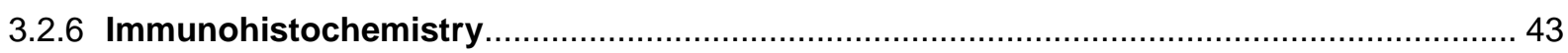

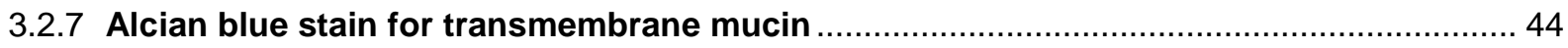

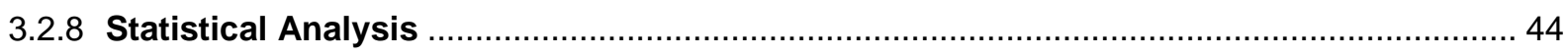

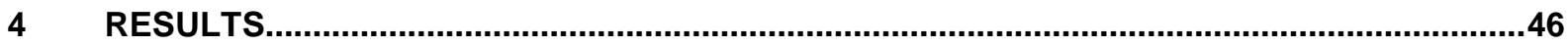

4.1 OVARIAN AND ENDOCRINE VARIABLES 46

4.2 ENDOMETRIAL VARIABLES 48

4.2.1 Effects of distinct pre-ovulatory endocrine profiles on endometrial transcripts at D0 ..... 48

4.2.2 Effects of distinct periovulatory endocrine profiles on endometrial transcripts at D4 .... 48

4.2.3 Effects of distinct periovulatory endocrine profiles on endometrial transcripts at D7 .... 49

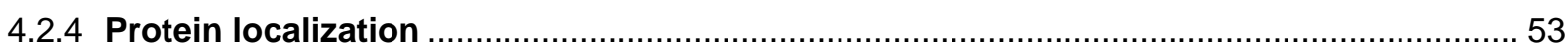

4.2.5 Steroid modulation of Mucin abundance in the endometrial epithelium ........................... 56

5 DISCUSSION

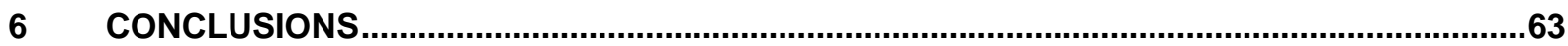

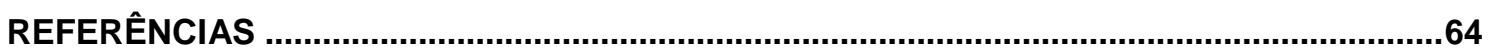




\section{INTRODUÇÃO GERAL}

O insucesso gestacional é o fator que, isoladamente, mais influencia a produtividade e a lucratividade de um rebanho bovino. Dessa forma, a perda gestacional ainda é alvo de intensas pesquisas devido à baixa eficiência reprodutiva na maioria das explorações pecuárias.

Apesar das melhorias realizadas ao longo das últimas décadas em técnicas de manipulação do ciclo estral, protocolos de sincronização, fertilização in vitro e transferência de embriões em bovinos, as taxas de concepção (número de animais gestantes/número de animais inseminados) têm melhorado apenas marginalmente. Estas observações reforçam a noção de que o útero exerce influências reguladoras chave sobre o desenvolvimento embrionário pré-implantação. Sabe-se, por exemplo, que a partir de taxas médias de fecundação de $90 \%$ e de natalidade de $55 \%$, os índices de mortalidade embrionária atingem $40 \%$ em fêmeas bovinas. Diskin e Sreenan (1980) relataram que 70 a $80 \%$ do total de perda embrionária ocorre entre os dias 8 e 16 após a inseminação, reforçando a importância do período préimplantacional para o estabelecimento de gestação. Durante tal período, o embrião é inteiramente dependente do ambiente intrauterino em que se encontra.

Deve-se ressaltar que o estabelecimento e manutenção da gestação são eventos complexos que requerem sintonia entre a receptividade uterina da fêmea e a capacidade do embrião em se desenvolver (SPENCER et al., 2007). Assim, o insucesso gestacional pode ser atribuído a uma inaptidão intrínseca do embrião, à inadequada receptividade endometrial ou a ambos. A presente dissertação focará nos aspectos relacionados ao endométrio.

O entendimento dos mecanismos moleculares responsáveis pela sobrevivência embrionária e consequente implantação é essencial para o desenvolvimento de técnicas que resultem na diminuição das perdas embrionárias e melhora nas taxas de gestação em bovinos, resultando, consequentemente, em um melhor aproveitamento do desempenho reprodutivo da fêmea bovina. Contudo, há limitada informação relacionada à identidade das moléculas sintetizadas e secretadas pelo endométrio na primeira semana do ciclo estral e que estão potencialmente associadas com a probabilidade de concepção. Apesar de variados estudos relatarem a expressão gênica diferencial do endométrio em diferentes fases 
do ciclo estral ou mesmo na gestação inicial, tais estudos em sua maioria abordam a fase luteal tardia do ciclo ou em torno do reconhecimento materno da gestação.

De modo geral, as oscilações hormonais fisiológicas que ocorrem no ciclo estral em ruminantes determinam fases distintas de dominância entre os hormônios esteroides sexuais, estradiol (E2) e progesterona (P4). Estudos sugerem que a P4 tem um importante papel no desenvolvimento embrionário precoce, mais precisamente dentro da primeira semana de gestação (SPENCER; BAZER, 2002; CARTER et al., 2008). Segundo Forde et al. (2011), existe uma variação temporal na composição e quantidade dos transcritos do endométrio da espécie bovina, de acordo com as mudanças nas concentrações de P4 circulantes que ocorrem nos primeiros dias após o estro. Além disso, a sequência e amplitude da exposição aos hormônios esteroides E2 e P4 é igualmente importante nessa regulação. O conceito de ambiente endócrino periovulatório provém de estudos como o de Vasconcelos et al. (2001), a partir do qual demonstrou-se que um folículo ovulatório maior tem maior capacidade de produção de E2, e que o tamanho deste folículo é positivamente correlacionado com o tamanho do $\mathrm{CL}$ formado a partir de sua ovulação e com a secreção de P4 luteal. Assume-se, portanto, que a sequência de exposição ao E2 e à $\mathrm{P} 4$ seja um conjunto de eventos fisiológicos que devem ser considerados como um todo. O presente estudo refere-se a estas variações hormonais como o ambiente endócrino da fase periovulatória, a qual envolve as concentrações de E2 durante o proestro e estro, bem como, ao subsequente aumento gradual pós-ovulatório das concentrações de P4.

A expressão de receptores de hormônios esteroides no endométrio é alterada durante o ciclo estral. Essas alterações influenciam na responsividade deste tecido alvo aos hormônios circulantes. Há evidencias da associação entre as variações da produção de E2 e P4 e a modulação da expressão de seus receptores. Populações uterinas de receptores de estrógenos (ER) e progesterona (PGR) são maiores no período periovulatório, em resposta aos estrógenos produzidos pelo folículo dominante pré-ovulatório. Além disso, entende-se que há relação entre a ativação desses receptores com a síntese e secreção de proteínas nas tubas uterinas e no endométrio (SPENCER; BAZER, 1995; STEWART et al., 2000; ULBRICH et al., 2009). Coletivamente, supõe-se que os efeitos dos esteroides sexuais femininos, E2 e P4, decorram da estimulação de seus receptores endometriais do endométrio levando a um padrão específico de expressão gênica do epitélio luminal, epitélio 
glandular e estroma. Nessa dissertação, a ação de cada esteroide sexual em momentos específicos do ciclo estral será denominada "tônus esteroidal" (do inglês, "sex steroid tone"). O tônus esteroidal é determinado pela concentração plasmática de E2 ou P4 e a abundância de seus respectivos receptores no endométrio, levando a uma resposta tecidual específica. No entanto, as respostas teciduais que se seguem à estimulação por E2 e P4 durante a primeira semana do ciclo estral, ainda não estão completamente elucidados e também são alvos de estudo na presente dissertação.

Especula-se que as moléculas diferencialmente expressas pela tuba e/ou endométrio e relacionadas aos efeitos positivos da exposição a concentrações mais altas de E2 (no proestro) e P4 (no diestro inicial) estejam envolvidas em processos relacionados ao suporte do desenvolvimento embrionário e adaptação do ambiente tubárico e uterino para a receptividade ao embrião, e assim propiciem maiores taxas de gestação nas vacas com maior crescimento do folículo pré-ovulatório.

Visando aumentar o entendimento de tais processos, o Laboratório de Fisiologia e Endocrinologia Molecular, onde o presente estudo foi conduzido, desenvolveu um modelo experimental no qual modulou-se o crescimento do folículo pré-ovulatório, sendo gerados dois grupos de animais, apresentando grande (FGCLG) ou pequeno (FP-CLP) folículo pré-ovulatório e subsequente $C L$. Consequentemente, o grupo FG-CLG foi associado a maiores concentrações plasmáticas de E2 no proestro e estro, e P4 no diestro inicial (MESQUITA et al., 2014). Ainda, o grupo FG-CLG foi associado a maior fertilidade e receptividade (PUGLIESI et al., 2015, submitted) ${ }^{1}$. Em dois experimentos independentes, tecido endometrial foi coletado de animais de ambos os grupos no dia zero (D0), quatro (D4) e sete (D7) do ciclo estral. O estudo apresentado nesta dissertação possui ampla relevância no entendimento do comportamento biológico dos hormônios esteroides e sua sinalização no endométrio bovino durante o período inicial da gestação.

Formulou-se, portanto, a hipótese geral de que alterações no perfil de hormônios esteroides acerca do período de receptividade uterina possui efeito sobre o sucesso gestacional. Buscou-se ganhar informação pertinente ao controle da

\footnotetext{
1 PUGLIESI, G.; SANTOS, F. B.; LOPES, E.; NOGUEIRA, E.; MAIO, J. R. G.; BINELLI, M. Improved fertility in suckled beef cows ovulating large follicles or supplemented with long-acting progesterone after timed-Al. Theriogenology (submitted), 2015.
} 
expressão dos receptores de E2 e P4 no diestro inicial e, principalmente, aumentar o entendimento do tônus esteroidal na modulação da composição do ambiente uterino de vacas e, consequentemente, na receptividade uterina ao embrião.

Os objetivos específicos deste trabalho foram comparar diferentes tônus esteroidais em três momentos do ciclo estral (DO, D4 e D7) na: (1) abundância dos transcritos e distribuição proteica de receptores de esteroides, (2) abundância de transcritos de genes alvos dos esteroides sexuais que regulam a função uterina e, (3) abundância e distribuição tecidual de mucina ao longo do epitélio glandular e luminal, uma glicoproteína indicadora de baixa receptividade endometrial.

Para tal, a presente dissertação contém dois capítulos sendo o primeiro capítulo composto por uma revisão de literatura e descrição dos conceitos e mecanismos relevantes neste trabalho. O segundo capítulo apresenta um estudo sobre a influência de um ambiente endócrino periovulatório contendo maiores ou menores concentrações de esteroides circulantes durante a primeira semana do ciclo estral sobre a abundância de transcritos ligados à sinalização dos receptores de esteroides no endométrio. Também, foi estudada a influência desta regulação em genes alvo dos esteroides. O segundo capítulo foi redigido em formato de artigo e será submetido com o título "Periovulatory sex steroid tone controls transcription and function of the bovine uterus". 


\section{CHAPTER 1: LITERATURE REVIEW}

In cycling females, uterine responses to ovarian hormones occur in a concerted manner. Sex steroid hormones, mainly estradiol-17ß (E2) and progesterone (P4), interact in a broad range of tissues regulating several physiological functions as well as gene expression; notwithstanding, it remains extremely difficult to determine the specific effects of sex steroids on the uterine environment. Given the central role on almost all aspects of female reproduction, there is a complex interplay between the action of E2 and P4 in the uterus tissue. Generally, in the uterus, E2 stimulate uterotropic responses, whereas P4 seen to be antagonistic to these estrogen-induced effects. Conversely, many of the physiological actions of P4 are dependent upon prior estrogen exposure.

The endometrium is a highly dynamic tissue that undergoes cyclical variation during estrous cycle. The endometrial changes are driven by the ovarian steroid hormones. Under the influence of the changing hormonal milieu, cellular proliferation, differentiation, and apoptosis occur in association with changes in extracellular matrix (ECM) composition. During the proliferative phase and under the influence of E2 there is a rapid cellular proliferation of all cell types. Following ovulation and under regulation by $\mathrm{P} 4$, the endometrium undergoes functional differentiation to provide a suitable environment for embryo implantation (SPENCER et al., 2004). Characteristically, the glands become increasingly tortuous with considerable secretory activity. In the absence of pregnancy, falling steroid hormone concentrations in the late secretory phase trigger endometrial regression and luteolysis.

The ovary, in mammal species, is the major site of synthesis and secretion of E2 and P4 what gives rise to cyclical fluctuations of these hormones. Primary follicles play a dual role in secreting both hormones as well as being responsible for the release of the oocyte during the normal cycle. Before ovulation, granulosa cells in the follicle biosynthesize and secrete E2. After follicle rupture and release of the oocyte, these granulosa cells developed to the corpus luteum $(\mathrm{CL})$, which is responsible for increases secretion of P4 in the diestrus. Both E2 and P4 action is mediated by endocrine signaling. Once released, E2 and P4 are carried in the blood by specific 
binding plasma proteins in order to reach its site of biological effect. Endocrine signaling depends upon three main factors: (1) the biosynthesis and secretion of the hormone; (2) its bioavailability to the target tissue; and (3) its intracellular availability to the effector proteins. The latter defines the hormonal responsiveness of the tissue.

Sex steroid hormones exert their cellular actions through various cellular pathways. The classical pathway for steroid hormones involves primarily binding to specific high-affinity receptors, which in turn act as transcription factors and modulate the transcription of responsive genes (HORWITZ; MCGUIRE, 1978). Nongenomic actions of E2 and P4 have also been reported due to its capacity of binding to membrane receptors, including G-protein coupled receptors (HALL; COUSE; $\mathrm{KORACH}, 2001)$. This chapter will describe the mechanisms by which steroids trigger tissue responses focused on the bovine endometrium and how the endocrine profile can affect this modulation.

\subsection{STEROID RECEPTORS: RELATIONSHIP BETWEEN HORMONAL TONE AND TISSUE RESPONSES}

Properly timed and coordinated events in response to the fluctuations in ovarian hormones are critical to acquisition of endometrial competence for early embryonic development. In fact, not only the E2 and P4 concentrations in peripheral blood are important, but also their binding to specific receptors within target cells and subsequent activation of transcription of steroid responsive genes are critical for the biochemical action of E2 and P4 at cellular level. The hormonal response is manifested as an alteration in cellular phenotype due to a receptor-dependent regulation of specific sets of responsive genes.

The predominant biological effects of E2 and P4 on the endometrium are mediated primarily by the binding to their nuclear receptors: estrogen receptor (ER) and $P 4$ receptor (PGR) respectively, which are located within the target cells in the uterus (MILGROM et al., 1973; HORWITZ; MCGUIRE, 1978). These receptors are member of a large superfamily of nuclear receptors, modular proteins that share a common structural and functional organization, with distinct domains consisting of a C-terminal or ligand-binding domain (LBD), a centrally located and highly conserved 
DNA-binding domain (DBD), and an N-terminal domain. Within these domains are at least two transcription activation functions (AFs): AF-1 which is located in the $\mathrm{N}$ terminal domain, and ligand-dependent AF-2, found on the LBD (HALL; COUSE; KORACH, 2001).

\subsubsection{Estrogen receptors}

Estrogens, acting via the ER, play important roles in regulating the growth, differentiation, and functioning of many reproductive tissues including the uterus, vagina, ovary, oviduct, and mammary gland. In the uterus, estrogens increase proliferation and alter cell properties by modulating transcription of estrogen responsive genes (HALL; COUSE; KORACH, 2001).

Two different ER genes, ESR1 and ESR2, are distinct gene loci that encode $E R \alpha$ and $E R \beta$, respectively, which share the ability to bind estrogens and regulate similar genes. The precise physiological role of subtypes of ER is not well understood. The DBD and LBDs of the ER subtypes are well conserved both the amino acid sequence level and structurally, whereas considerable divergence is apparent in the N-terminal region (PAECH et al., 1997; HIROI et al., 1999). Both ER subtypes recognize similar target DNA sequences, and bind and respond similarly to endogenous estrogens such as E2, estrone, or estriol, although there are differences in DNA-binding affinity and specificity for ligands (PAECH et al., 1997). Although ERa and ER $\beta$ are coexpressed in female reproductive tissues (KUIPER et al., 1997), they also exhibit different tissue/cell expression patterns and are functionally distinct (HIROI et al., 1999; WANG et al., 1999). ERa is related as more potent transcriptional activator than ER $\beta$, and in tissue where both ERs are expressed, ER $\beta$ has been suggested to have a role as an attenuator of ERa (KUIPER et al., 1997). Generally, ER $\alpha$ and ER $\beta$ can form both homo- and heterodimers before attaching to DNA. In the endometrium, many of E2 actions may be mediated by ERa which is the predominant form reported in the uterus, while subtype ER $\beta$ has not yet been demonstrated (WANG et al., 1999).

Further evidence of distinct biological functions for the ERs is revealed by the contrasting phenotypes observed in the individual lines of ER-null mice; these 
models provide insights into the isoform-specific receptor-mediated effects of estrogen in the regulation of uterine function. The most prominent phenotypes in the female ERa null mice include estrogen insensitivity in the reproductive tract, which combines with severe deficits in sexual behavior, result in complete infertility (DUPONT et al., 2000). In contrast, the ERß null females exhibit inefficient ovarian function and subfertility (WANG et al., 1999; DUPONT et al., 2000).

The classical pathway for how estrogens regulate gene expression has been examined extensively (Figure 1), however, numerous variations in this mechanism also have been described. Activated ERs are transcription factors that bind in dimeric form to estrogen response element (ERE), specific sequences of DNA typically located in the promoter regions of estrogen responsive genes. The consensus ERE sequences is a 13 base pair inverted repeat sequence, GGTCAnnnTGACC (KLEINHITPASS et al., 1988); although the majority of response element sequences contain one or more variations from the consensus (HALL; COUSE; KORACH, 2001). The mechanism by which ERs mediate transcription involves interaction of the AFs a complex of molecules that assembles and ultimately results in synthesis of mRNA. The ligand-ER complex then recruits the transcriptional co-modulators and interact with components of the transcriptional complex to modulate gene transcription. Depending on the cell and promoter context, the DNA-bound receptor exerts either a positive or a negative effect on expression of the downstream target gene (CURTIS et al., 1996). An interesting aspect is the specificity or type of estrogenic response elicited by estrogens in the target cells. That is, the multiple molecular factors present in each cell or tissue that interact with the estrogen-ER complexes, changing the ability of these complexes to interact with DNA response elements (MCDONNELL et al., 1995). In summary, under physiological conditions, each cell type has a unique molecular milieu that influences that final response of the cell to an estrogen stimulus.

The rapid action of estrogens independent of gene transcription has been namely nongenomic to distinguish it from direct, or genomic, effects on gene expression in the nucleus. Pietras and Szego (1975) provided the first evidence of the existence of activate signal cascades at the cell membrane that could be responsible for mediating effects of estrogen. Some estrogen-initiated rapid effects are mediated through a G-protein-coupled mechanism and able to elicit a variety of signal transduction events, including the induction of cell proliferation. These rapid effects 
can be initiated by BSA-conjugated steroids, which cannot enter the cell but can interact with the surface, indicating that extracellular components are sufficient to initiate response (FILARDO et al., 2000). One potential candidate is GPER, a Gprotein-coupled receptor that has been shown to bind to estrogen, resulting in MAPK activity as well as adenylate cyclase activity through a Ga protein (FILARDO et al., 2000). 


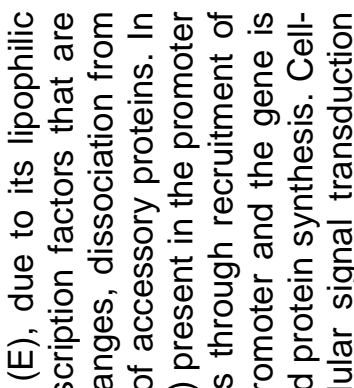

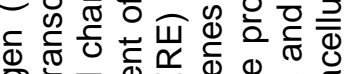

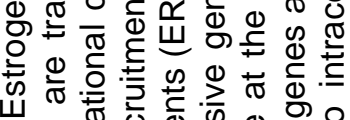
क

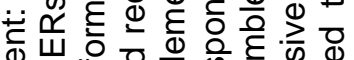

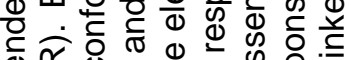
ब्य

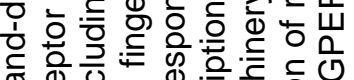

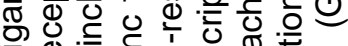
에

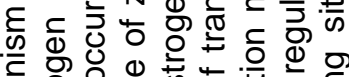

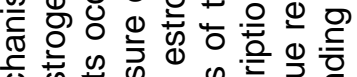

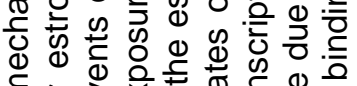

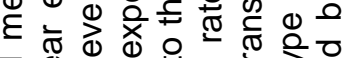

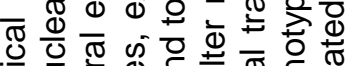

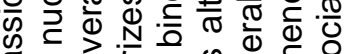
잉

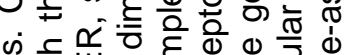

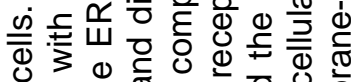

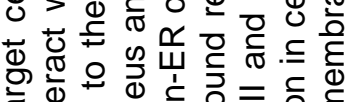
कٓ 드. ธ

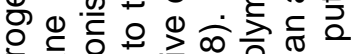
类

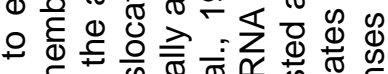
0 एक क

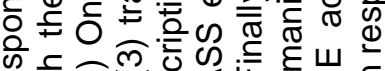
के

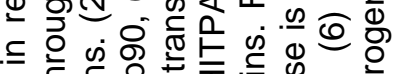
다웡 0

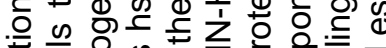
준 ब次

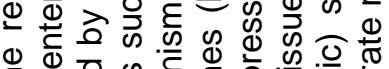

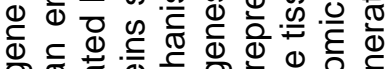

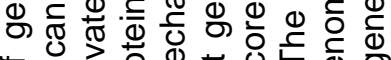
후응 है

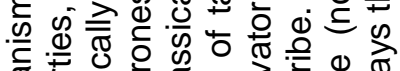
娄

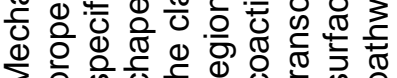

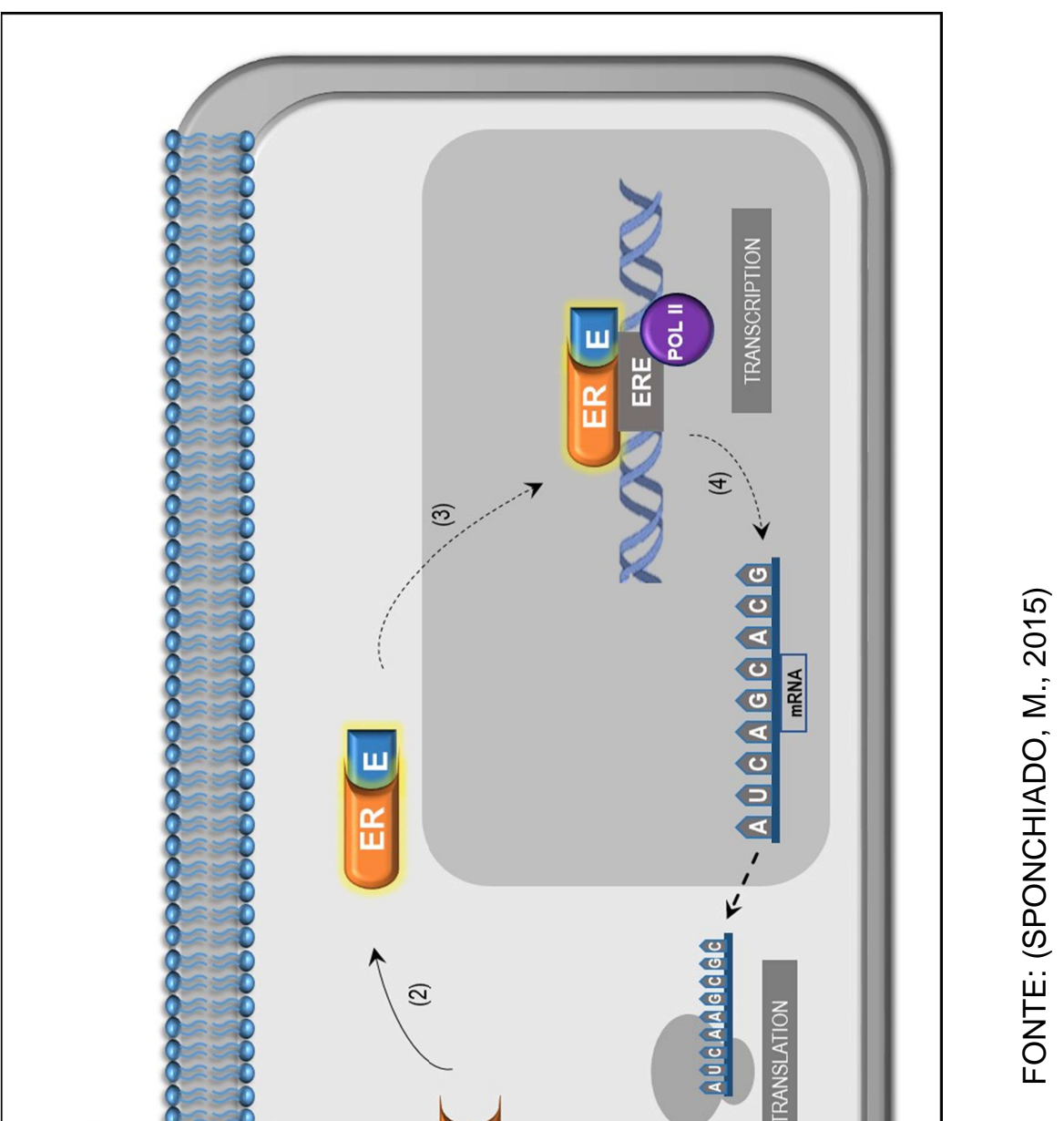

흔 


\subsubsection{Progesterone receptors}

The ovarian steroid hormone P4 is a critical regulator of reproductive events associated with all aspects of the establishment and maintenance of pregnancy. Well characterized functions of $\mathrm{P} 4$ include regulating the timing of the estrus cycle and the pregnancy in domestic animals, including cows (NISWENDER et al., 2000). This hormone affects endometrial development and facilitates blastocyst implantation within the uterus and fetal development and maintenance of pregnancy (SPENCER et al., 2004).

Most of the physiological effects of P4 are mediated through its nuclear receptor. PGR is encoded in one gene and exists as several isoforms with the most well characterized being three isoforms: a full-length form (PGR-B, 110kDa), an Nterminally truncated form (PGR-A, 86kDa) and a form C (PGR-C, 76kDa). These isoforms arise from either alternative transcriptional or translational start sites. PGR isoforms differ in their ability to activate distinct target genes in the same cell. PGR-B usually acts as a transcriptional activator, whereas PGR-A acts as an inhibitor (MOTE et al., 2006).

Both PGR-A and PGR-B are expressed in the uterus at approximately equivalent abundance (MULAC-JERICEVIC; CONNEELY, 2004). Recent studies proposed the relative contributions of these individual isoforms to P4-dependent uterine activity. Expression of PGR-A is necessary and sufficient to mediate both the antiproliferative and implantation-associated responses to P4. In contrast, selective expression of PGR-B in the uterus of PGR-A null mice results in disrupted regulation of a subset of epithelial markers of uterine receptivity (MOTE et al., 2006).

Recent studies have reported that P4 can also affect cell response though a membrane receptors with P4 binding activity, referred as progesterone receptor membrane component (PGRMC) 1 and 2 (LÖSEL et al., 2008; GELLERSEN; FERNANDES; BROSENS, 2009). This represent a via of fast action, because P4 can change the cell response through nongenomic mechanism. The presence of PGRMCs in the cow reproductive tissue have been documented by Luciano et al. (2011), but then role has not been well known. 


\subsection{REGULATION OF STEROID RECEPTORS IN THE ENDOMETRIUM}

Regulation of receptors is an important step of steroid signaling and that determines the tissue responsiveness to hormonal stimulus. This regulation is coordinated primarily by abundance and bioavailability of the receptors. This may occurs by increasing or decreasing receptor synthesis, by availability of receptors prior ligand binding, or by uncoupling of the receptor from its signal transduction pathway (desensitization). The latter usually involves phosphorylation of the steroid receptor (HORWITZ; MCGUIRE, 1978).

During the estrous cycle, the bovine endometrium exhibits characteristic morphological and functional changes, which are mainly orchestrate by steroid hormone fluctuations. The abundance of steroid receptors in the uterus is largely steroid hormone regulated. Endometrial distribution of steroid receptors is regulated accross the estrous cycle and early pregnancy in a cell-specific manner in ewe (SPENCER; BAZER, 1995) and in cattle (KIMMINS; MACLAREN, 2001). In the proliferative phase of the endometrial cycle, occurring before ovulation, the uterus is primarily under the control of $\mathrm{E} 2$, which is secreted in increasing quantities by the dominant follicle. The stromal cells and the epithelial cells proliferate rapidly at the first stage. During the proliferative phase, greater abundance of ERa and PGR are present in the nuclei of epithelial and stromal cells of the bovine endometrium (ROBINSON et al., 2001).

The secretory phase of the endometrial cycle begins after ovulation. Continued E2 causes slight additional cellular proliferation in the endometrium, while P4 from the newly formed CL causes marked swelling and secretory development. As circulating concentration of P4 increase during the subsequent luteal phase, both receptor types decrease and reach nadir tissue concentrations during the mid-luteal phase of the estrous cycle. In most mammalian uteri, progesterone receptors (PGR) are expressed in endometrial epithelia and stroma during the early to mid-luteal phase, allowing direct regulation (induction or repression) of genes by $\mathrm{P} 4$. However, continuous exposure of the endometrium to P4 negatively regulates PGR expression in the LE and then glandular epithelium (GE), and the downregulation of PGR is temporally associated with the induction of many progesterone-stimulated genes. Indeed, the paradigm of loss of PGR in uterine epithelia immediately prior to 
implantation is common across mammal. In sheep, PGR loss from the uterine epithelia is determined by timing of the post-ovulatory rise in $\mathrm{P} 4$ and requires continuous exposure to P4 for at least 8 days (SPENCER; BAZER, 1995). Thus, an early increase in circulating $P 4$ apparently advances the timing of PGR loss form uterine epithelia (SATTERFIELD; BAZER; SPENCER, 2006). Of interest, Okumu et al. (2010) and Bridges et al. (2012) observed decreased expression of PGR in the endometrium on D13 and D15.5 of estrus cycle, respectively, in pregnant compared with non-pregnant cattle. In livestock species, for proper expression of various proteins and secretions from the endometrium during gestation, the temporal and spatial regulation of the PGR is essential (SPENCER; BAZER, 1995; SATTERFIELD; BAZER; SPENCER, 2006). Disappearance of the PGR allows for the increased secretion of the uterine products required to support conceptus development. Among these include uterine histotroph. Uterine histotroph is composed of transport proteins, ions, cytokines, enzymes, hormones, growth factors, proteases and protease inhibitors, amino acids, glucose, fructose, vitamins, and adhesion molecules (BAZER et al., 2011).

Silencing of PGRs and ERa in the endometrial epithelia is a prerequisite for implantation, since allow expression of genes related to secretory proteins, and selective transport of molecules into the uterine lumen to create histotroph that is essential for conceptus growth and development (SPENCER; BAZER, 1995). Differential expression of genes by uterine epithelia and stromal cells in response to P4 is considered essential for successful embryo implantation in most mammals. Therefore, there is a paradox between the increase of $\mathrm{P} 4$ and the loss of their cellular mediators in the endometrium. It seems reasonable assume that not all actions of P4 are mediated by their nuclear receptors. 


\section{CHAPTER 2: PERIOVULATORY SEX STEROID TONE CONTROLS TRANSCRIPTION AND FUNCTION OF THE BOVINE UTERUS}

\subsection{INTRODUCTION}

The molecular mechanisms underlying the interaction of mammalian embryos with the endometrium remain a fundamental and elusive topic in developmental and cell biology. In spite of improvements made over the last decades in techniques of estrous cycle manipulation, synchronization protocols and in vitro fertilization/embryo transfer in cattle, pregnancy success rates have improved only marginally. These observations have reinforced the notion that the uterus exerts key regulatory influences over the pre-implantation embryo development. In ruminants, the periimplantation period has received great attention, due to the high proportion of pregnancies that fail during this period. In cattle, Diskin and Sreenan (1980) reported that 70 to $80 \%$ of all embryonic losses occur between days 8 and 16 after insemination, reinforcing the importance of this period for the gestation establishment.

Focusing on the maternal reproductive tract, the bovine endometrium is a dynamic tissue that undergoes spatiotemporal functional changes orchestrated by ovarian hormones, estradiol-17 (E2) and progesterone (P4). Timing and magnitude of changes in circulating concentration of sex steroids around ovulation are associated with reproductive tract receptivity and, ultimately, fertility (CARTER et al., 2008; BRIDGES et al., 2010; PUGLIESI et al., 2015, submitted ${ }^{2}$ ). However, not only the E2 and P4 concentrations in peripheral blood are important, but also their binding to specific receptors within target cells and subsequent activation of transcription of steroid responsive genes are critical for the biochemical action of E2 and P4 at the cellular level. Whereas variation in the circulating amounts of these hormones has long been known to control the response of target cells, another layer of mechanistic control is the abundance and activity of steroid hormone receptors.

\footnotetext{
${ }^{2}$ PUGLIESI, G.; SANTOS, F. B.; LOPES, E.; NOGUEIRA, E.; MAIO, J. R. G.; BINELLI, M. Improved fertility in suckled beef cows ovulating large follicles or supplemented with long-acting progesterone after timed-Al. Theriogenology (submitted), 2015.
} 
The predominant biological effects of E2 and P4 on the endometrium are mediated primarily by the binding to their nuclear receptors: estrogen receptor (ER) and $\mathrm{P} 4$ receptor (PGR) respectively, which are located within the target cells in the uterus (MILGROM et al., 1973; HORWITZ; MCGUIRE, 1978). Both receptors belong to a superfamily of nuclear receptors, which is a family of ligand-regulated transcription factors that are activated by lipid-soluble signal, such as steroid hormones.

E2 mediates its functions through the two subtypes of its receptors, ERa and ER $\beta$, which are coded by distinct gene loci, ESR1 and ESR2, respectively. These forms have analogous capacity to bind estrogens and regulate similar genes (PAECH et al., 1997). The precise physiological role of subtypes of ER is not well understood. Although ERa and ER $\beta$ are coexpressed in female reproductive tissues (KUIPER et al., 1997), they also exhibit different tissue/cell expression patterns and are functionally distinct (HIROI et al., 1999; WANG et al., 1999). In the endometrium, many of E2 actions may be mediated by ERa which is the predominant form reported in the uterus (WANG et al., 1999).

In the uterus, E2 increases proliferation and alters cell properties by modulating transcription of estrogen responsive genes. Activated ERs are transcription factors that bind in dimeric form to estrogen response element (ERE), specific sequences of DNA typically located in the promoter regions of estrogen responsive genes. The consensus ERE sequences is a 13 base pair inverted repeat sequence, GGTCAnnnTGACC (KLEIN-HITPASS et al., 1988). The ligand-ER complex then recruits the transcriptional co-modulators and interact with components of the transcriptional complex to modulate gene transcription. Depending on the cell and promoter context, the DNA-bound receptor exerts either a positive or a negative effect on expression of the downstream target gene (HALL; COUSE; KORACH, 2001).

Most of the physiological effects of P4 are mediated through its nuclear receptor. PGR is encoded by the same gene and exists as several isoforms with the most well characterized being three isoforms: a full-length form (PGR-B, 110kDa), an $\mathrm{N}$-terminally truncated form (PGR-A, 86kDa) and a form C (PGR-C, 76kDa). These isoforms arise from either alternative transcriptional or translational start sites. PGR isoforms differ in their ability to activate distinct target genes in the same cell 
(MULAC-JERICEVIC; CONNEELY, 2004; MOTE et al., 2006). PGR-B usually acts as a transcriptional activator, whereas PGR-A acts as an inhibitor (MOTE et al., 2006).

However, not all of the actions of E2 and P4 are mediated through its interactions with nuclear receptors. It is now clear that E2 and P4 can also affect target cells through nongenomic actions due to its capacity of binding to membrane receptors, including G-protein coupled receptors. The rapid action of sex steroids independent of gene transcription has been namely nongenomic to distinguish it from direct, or genomic, effects on gene expression in the nucleus. One potential candidate is GPER, a G-protein-coupled receptor that has been shown to bind to estrogen, resulting in MAPK activity as well as adenylate cyclase activity through a Ga protein (FILARDO et al., 2000). Novel membrane receptors with P4 binding activity, referred to as progesterone receptor membrane component (PGRMC) 1 and PGRMC2, provide a candidate for nongenomic action of P4 (LÖSEL et al., 2008), including in the bovine uterus (LUCIANO et al., 2011).

Endometrial distribution of steroid receptors is regulated across the estrous cycle and early pregnancy in a cell-specific manner. Elevated E2 (from proestrus and estrus) followed by increasing P4 on early diestrus induces coordinated autoregulation of their receptors (SPENCER; BAZER, 1995; ROBINSON et al., 2001). Simplistically, in cattle, the preovulatory rise in E2 increases the expression both PGR and ERa in the uterine endometrium (SPENCER; BAZER, 1995). As circulating concentration of P4 increase during the subsequent luteal phase, abundance of both receptor types decrease and reach nadir tissue concentrations during the mid-luteal phase of the estrous cycle (KURITA et al., 1998). In the pregnant cow, downregulation of the $P G R$ in endometrium is a critical event required for proper uterine function during gestation (SPENCER et al., 2004; SATTERFIELD et al., 2006).

Collectively, the temporal changes in circulating levels of sex steroids, the diversity and highly regulated transcriptional and post-transcriptional expression of sex steroid receptors, receptor binding, signaling and transactivation activity characterize a dynamic "sex steroid tone" during the periovulatory period. It follows that activation of sex steroid target genes depends on the tone present at a given moment. It is reasonable to propose that different tones are associated with different target tissue phenotype and function. Specifically regarding the pre-implantation endometrium, our overarching hypothesis is that different sex-steroid tones are associated with different degrees of receptivity and fertility. 
We have characterized an animal model that modulates the periovulatory sex steroid milieu in beef cattle (MESQUITA et al., 2014). In that model, animals that ovulated larger follicles presented greater proestrus-estrus concentrations of E2 and diestrus concentrations of P4 (i.e., the Large Follicle - Large CL group; LF-LCL) compared to cows that ovulated smaller follicles (the Small Follicle - Small CL group; SF-SCL). Moreover, in a fertility trial, the proportion of cows pregnant on the LF-LCL group was greater than that of the SF-SCL group (PUGLIESI et al., 2015, submitted $)^{3}$. Furthermore, the endometrial transcriptome measured on day 7 of the estrous cycle was distinctly different between the two groups (MESQUITA et al., 2015 , in press) ${ }^{4}$. Most importantly, such changes in the transcriptome were reflected on different proliferative (MESQUITA et al., 2015, in press) $)^{5}$ and redox uterine phenotypes between groups (RAMOS et al., 2015). Here, we have used the animal model described by Mesquita et al. (2014) to determine the influence of different periovulatory endocrine milieus on the expression of transcripts associated with sexsteroid-dependent responses in the endometrium during the first week post-estrus in cattle. Specific objectives were to compare between the LF-LCL and the SF-SCL groups: 1. steroid receptors gene expression (ESR1, ESR2, GPER, PGR1, PGR2, $P G R 3, P G R M C 1, P G R M C 2)$ and protein distribution, (2) expression of steroid responsive genes that regulate the following uterine functions: proliferation (growth regulation by estrogen in breast cancer 1, GREB1; cyclin D1, CCND1; wingless-type MMTV integration site family, member 5A, WNT5a; fibroblast growth factor 2, FGF2), secretory activity (serpin peptidase inhibitor, clade A member 14, SERPINA14; lactotransferrin, LTF; nuclear receptor interacting protein 1, NRIP1), extracellular matrix remodeling (matrix metallopeptidase 2, MMP2), aqueous transport (aquaporin 4, AQP4) and cell-adhesion (mucin 1 cell surface associated, MUC1) and (3) abundance and distribution of epithelial mucin, a glycoprotein that indicates poor endometrial receptivity.

\footnotetext{
${ }^{3}$ PUGLIESI, G.; SANTOS, F. B.; LOPES, E.; NOGUEIRA, E.; MAIO, J. R. G.; BINELLI, M. Improved fertility in suckled beef cows ovulating large follicles or supplemented with long-acting progesterone after timed-AI. Theriogenology (submitted), 2015.

${ }_{4,5}$ MESQUITA, F. S.; RAMOS, R. S.; PUGLIESI, G.; ANDRADE, S. C. S.; VAN HOECK, V.; LANGBEEN, A.; OLIVEIRA, M. L.; GONELLA-DIAZA, A. M.; GASPARIN, G.; FUKUMASU, H.; PULZ, L. H.; MEMBRIVE, C. M. B.; COUTINHO, L. L.; BINELLI, M. The receptive endometrial transcriptomic signature indicates an earlier shift from proliferation to metabolism at early diestrus in the cow. Biology of Reproduction (in press), 2015.
} 


\subsection{MATERIAL AND METHODS}

\subsubsection{Animals and reproductive management}

Experiments were carried out at the University of São Paulo in Pirassununga, São Paulo, Brazil. Animal procedures were approved by the Ethics and Animal Handling Committee of the School of Veterinary Medicine and Animal Science of the University of São Paulo (CEUA-FMVZ/USP, no 3125/2013), which complies with the ethical principles in animal research.

Two non-contemporaneous experiments were conducted. In each, 56 (Experiment 1) and 83 (Experiment 2) multiparous, cycling and non-lactating Nelore (Bos taurus indicus) cows presenting no gross reproductive abnormalities by gynecological examination, with body condition score between 3 and 4 (1, emaciated; 5 , obese) started the experiment. Cows were maintained under grazing conditions supplemented with chopped sugarcane and/or corn silage, concentrate and minerals to fulfill their maintenance requirements, and water ad libitum. Hormonal protocol and experimental design (Figure 2) used in both experiments were published previously by our group (MESQUITA et al., 2014).

\section{Experiment 1}

Ovarian follicular growth was controlled by hormonal treatments to generate two groups of animals, presenting a large (LF-LCL) or small (SF-SCL) preovulatory follicle (POF) and subsequent CL. Consequently, LF-LCL group was associated with greater proestrus concentrations of E2 and diestrus concentrations of $\mathrm{P} 4$, which were previously associated with greater receptivity and fertility (PERRY et al., 2005; MENEGHETTI et al., 2009; PERES et al., 2009; PUGLIESI et al., 2015, submitted) ${ }^{6}$. Briefly, animals ( $n=56)$ were pre-synchronized by two intramuscular (i.m.) injections of prostaglandin F2 $\alpha$ analogue (PGF2a; $0.5 \mathrm{mg}$ of sodium cloprostenol; Sincrocio ${ }^{\circledR}$, Ourofino Saúde Animal, Cravinhos, Brazil), 14 days apart. At the second PGF2 $\alpha$

\footnotetext{
${ }^{6}$ PUGLIESI, G.; SANTOS, F. B.; LOPES, E.; NOGUEIRA, E.; MAIO, J. R. G.; BINELLI, M. Improved fertility in suckled beef cows ovulating large follicles or supplemented with long-acting progesterone after timed-Al. Theriogenology (submitted), 2015.
} 
injection of pre-synchronization (D-20) animals received an Estrotect heat detector patch (Rockway, Inc. Spring Valley, WI, USA), and estrus detection was performed twice daily from $D-19$ to $D-16$ and once daily from $D-15$ to $D-10$. Only animals that displayed estrus after the second PGF2 $\alpha$ treatment and that contained new, PGF2 $\alpha$ responsive CL (at least 5 days old) on D-10 stayed in the experiment. Remaining cows $(n=41)$ received an intravaginal P4-releasing device $\left(1 \mathrm{~g}\right.$; Sincrogest ${ }^{\circledR}$, Ourofino Saúde Animal) on D-10 along with an i.m. injection of $2 \mathrm{mg}$ estradiol benzoate (Sincrodiol $^{\circledR}$, Ourofino Saúde Animal). Also on D-10, cows received (LF-LCL group) or not (SF-SCL group) a single i.m. PGF2a treatment to modulate the POF growth. The P4 devices were removed $42 \mathrm{~h}$ before the gonadotropin-releasing hormone $(\mathrm{GnRH})$ treatment and PGF2 $\alpha$ was administered in the LF-LCL group $(n=20)$. At the same time, cows from the SF-SCL group $(n=21)$ also received a dose of PGF2 $\alpha$, however, the P4 device was only removed 12 hours later. All animals received a second PGF2 $\alpha$ injection 6h later. On D0, ovulation was induced by an injection of

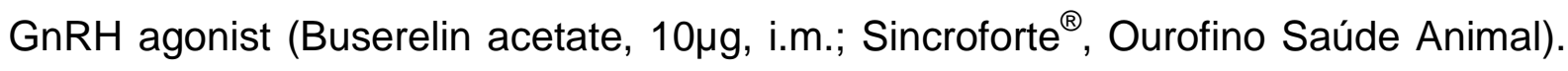
In addition, an endometrial biopsy was performed on D0.

In order to assess follicle growth, ovulation of the POF, CL area and blood flow, transrectal ultrasound examinations were carried out on D-10 and D-6, daily from D-2 to D0 and from D3 to D7, and every $12 \mathrm{~h}$ on D1 and D2. Ultrasonography was performed with the aid of a duplex B-mode (gray-scale) and pulsed-wave color Doppler ultrasound instrument (MyLab30 Vet Gold; Esaote Healthcare, São Paulo, SP, Brazil) equipped with a multifrequency linear transducer. Ovulation was defined as the disappearance of the previously identified POF followed by the observation of a $\mathrm{CL}$ on the same approximate topographical location on the ovary. The diameter of follicles was calculated as the average between measurements of two perpendicular axes of each structure. The maximum CL area was determined using a B-mode still image and the tracing function. For CL with an anechoic fluid-filled cavity, the area of the cavity was subtracted from the total area.

By design, animals were evaluated according to a set of minimal premises to remain in the data analyses. Animals were excluded from the experiment if: P4 concentration on D-10 was less than $1 \mathrm{ng} / \mathrm{mL}, \mathrm{P} 4$ concentration on D-2 was greater than $3 \mathrm{ng} / \mathrm{mL}$ in the LF-LCL group, P4 concentration on D-2 was less than $2 \mathrm{ng} / \mathrm{mL}$ in the SF-SCL group, dominant follicle diameter on D0 was less than $8 \mathrm{~mm}$, ovulation was detected at the D0 ultrasound examination or before (i.e., early ovulation), 
ovulation was detected at the D3 ultrasound examination (i.e., late ovulation), ovulation was not detected, or follicular or luteal cysts were detected at any moment during the experiment. Animals that responded to treatments as planned ( $\mathrm{n}=8, \mathrm{SF}$ $\mathrm{SCL} ; \mathrm{n}=16$, LF-LCL) were slaughtered 4 days post- induction of ovulation.

Figure 2 - Schematic representation summarizing the experimental model to generate two groups of cows, presenting a large (LF-LCL) or small (SF-SCL) preovulatory follicle and subsequent corpus luteum

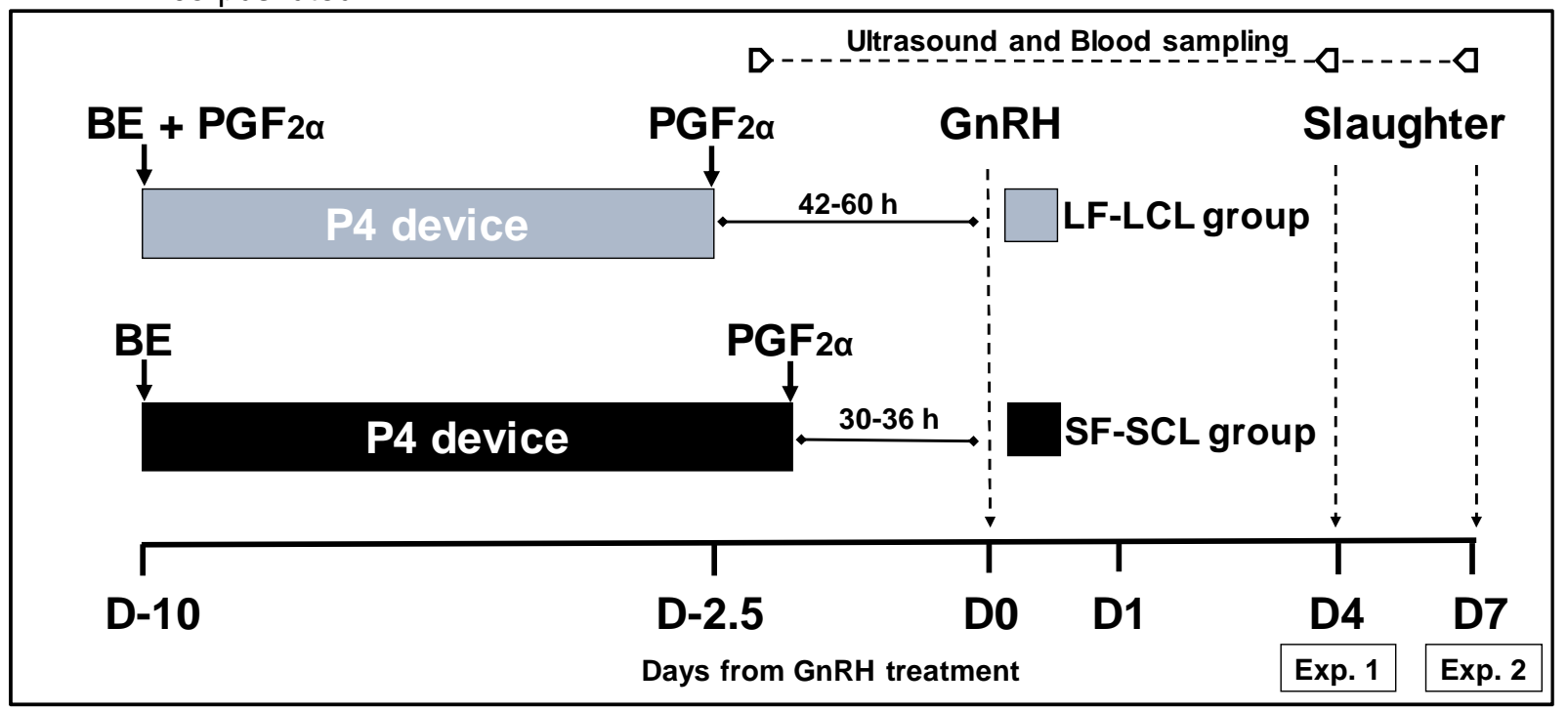

Fonte: (SPONCHIADO, M., 2015)

Notes: Cows were pre-synchronized by two injections of prostaglandin F2 $\alpha$ (PGF2 $\alpha ; 0.5 \mathrm{mg}$ of sodium cloprostenol; Sincrocio ${ }^{\circledR}$, Ourofino) given 14 days apart. On Day-10 (D-10), cows received a progesterone-releasing device (1 $\mathrm{g}$; Sincrogest ${ }^{\circledR}$; Ourofino) and an injection of $2 \mathrm{mg}$ estradiol benzoate (BE; Sincrodiol ${ }^{\circledR}$, Ourofino). On D-10, cows in the LF-LCL group also received an injection of PGF2a. On the day the progesterone-releasing device was removed, all cows received PGF2a. On D0 ovulation was induced with $1 \mu \mathrm{g}$ of gonadotropin-releasing hormone analog $(\mathrm{GnRH}$; buserelin acetate; Sincroforte ${ }^{\circledR}$, Ourofino). Cows were slaughtered on D4 (Experiment 1) or D7 (Experiment 2) and the reproductive tract was collected and dissected.

\section{Experiment 2}

Animals $(n=83)$ were hormonally manipulated using the same protocol described in Experiment 1 (Figure 2), except that the first PGF2a dose in the SF-SCL group was injected at the same time of the P4 device removal. Animals were slaughtered on D7 post-GnRH for collection of endometrial tissue. From the animals that were pre-synchronized, remaining cows $(n=74)$ were divided to compose the SFSCL $(n=39)$ or LF-LCL $(n=35)$ group. Of these, a subset of animals (SF-SCL, $n=8$; LF-LCL, $\mathrm{n}=9$ ) that responded to treatments as planned (and described in Experiment 1) were selected for further analysis. 


\subsubsection{Blood sampling and hormone measurements}

Blood plasma samples were collected daily from D-2 to D0 for measurement of E2 concentrations and for analyses of P4 concentrations on D-10, D- 1 and D-2, and daily from D1 to D4 (Experiment 1) or from D1 to D7 (Experiment 2). Samples were collected by jugular venipuncture in evacuated tubes containing heparin (BD, São Paulo, SP, Brazil) and stored on ice until plasma separation. Plasma was separated by centrifugation at $4{ }^{\circ} \mathrm{C}, 1,500 \times \mathrm{g}$ for $30 \mathrm{~min}$, and stored at $-20{ }^{\circ} \mathrm{C}$.

Plasma $\mathrm{P} 4$ concentrations were measured by solid-phase radioimmunoassay (RIA; Coat-A-Count Progesterone; Diagnostic Products Corporation, Los Angeles, CA, USA), validated to bovine plasma samples as previously described (GARBARINO et al., 2004). Plasma E2 concentrations were assayed using a commercial RIA kit (Double Antibody Estradiol; Diagnostic Products Corporation) as reported previously (SIDDIQUI et al., 2009). The intra-assay CV and sensitivity were $1.7 \%$ and $0.13 \mathrm{pg} / \mathrm{mL}$ for E2; and $0.8 \%$ and $0.05 \mathrm{ng} / \mathrm{mL}$ for P4, respectively.

\subsubsection{Collection of reproductive tract samples}

In Experiment 1, an endometrial biopsy was performed on D0, as described previously (Pugliesi et al., 2014). Endometrial tissue was collected from the uterine horn ipsilateral to the POF, immediately frozen in liquid nitrogen and placed at -80 ${ }^{\circ} \mathrm{C}$. Animals were observed for the presence of clinical disorders or vulvar discharge.

On D4 (Experiment 1) or D7 (Experiment 2), cows were stunned by captive bolt and killed by jugular exsanguination. Reproductive tracts were isolated and transported on ice to the laboratory within $10 \mathrm{~min}$ and the uterus was dissected. The uterine horn ipsilateral to the ovary containing the $\mathrm{CL}$ was longitudinally incised (antimesometrial side) and inter-caruncular endometrial fragments were dissected from the medial third and pooled. Once collected, the uterine samples were placed in cryotubes, snap frozen in liquid nitrogen and stored at $-80{ }^{\circ} \mathrm{C}$ for RNA and protein analysis. In addition, endometrial samples were fixed in $4 \%$ Tris-buffered 
formaldehyde and embedded in paraffin using standard procedures for histological examination.

The CL was excised, measured and weighed. Volume ( $V$ ) of the CL was calculated by applying measurements of height, width and length in the ellipsoid volume formula: $V=4 / 3 \pi \times r 1 \times r 2 \times r 3$, where $\pi$ is the mathematical constant, $r 1$ is height radius, $r 2$ is width radius and $r 3$ is length radius.

\subsubsection{RNA isolation and cDNA synthesis}

Frozen biopsy samples from D0 $(\approx 30 \mathrm{mg})$ were macerated in liquid nitrogen using a stainless steel apparatus and immediately mixed with RLT buffer from AlLPrep $^{\circledR}$ DNA/RNA/Protein Mini kit (№ 80004, Qiagen Laboratories, São Paulo, SP, Brazil). RNA extractions were conducted as recommended by the manufacturer's instructions. Tissue suspension was passed at least 5 times through a 21-ga needle, and centrifuged at $13,000 \times \mathrm{g}$ for $3 \mathrm{~min}$ for removal of debris, before supernatant loading and processing in silica columns.

Endometrial fragments from D4 and D7 ( $\approx 40 \mathrm{mg})$ were macerated in liquid nitrogen using a stainless steel apparatus, immediately homogenized in lysis buffer from the RNeasy mini columns Kit (Qiagen Laboratories) and further RNA extraction performed as per manufacturer's instructions. To maximize lysis, tissue suspension was passed at least ten times through a 21-ga needle, and centrifuged at $12,000 \mathrm{~g}$ for 1 min at $4 \stackrel{\circ}{\circ}$ for removal of debris, prior to supernatant loading and processing in RNeasy columns. Additionally, samples were treated with DNase I (Life technologies, Frederick, MD, USA) for $15 \mathrm{~min}$ at room temperature during the RNA extraction protocol. Columns were eluted with $30 \mu \mathrm{L}$ of RNase free water. Concentration and

purity of total RNA in extracts were evaluated using spectrophotometry (NanoVue ${ }^{\mathrm{TM}}$ Plus Spectrophotometer, GE Healthcare, UK) by the absorbance at $260 \mathrm{~nm}$ and the $260 / 280 \mathrm{~nm}$ ratios, respectively. The cDNA was synthesized by reverse-transcription using High-Capacity cDNA Reverse Transcription Kit (Life Technologies) from a fixed amount of RNA $(1 \mu \mathrm{g})$ per sample, following the manufacturer's instructions. Samples were incubated at $25^{\circ} \mathrm{C}$ for $10 \mathrm{~min}$, followed by incubation at $37^{\circ} \mathrm{C}$ for $2 \mathrm{~h}$ and 
reverse-transcriptase inactivation at $85{ }^{\circ} \mathrm{C}$ for $5 \mathrm{~min}$ and storage at $-20{ }^{\circ} \mathrm{C}$. Reverse transcriptase products were diluted in nuclease-free water and stored at $-20{ }^{\circ} \mathrm{C}$.

\subsubsection{Quantitative PCR}

The abundance of specific mRNA transcripts was determined by Real-Time reverse transcription PCR. Optimal primers pairs were designed based on GenBank Ref-Seq mRNA sequences of target genes. Sequences were masked to remove repetitive sequences with RepeatMasker (http://www.repeatmasker.org/) (SMIT; HUBLEY; GREEN, 1996-2010.). Subsequently, the masked sequences were used to primer design using the PrimerQuestQM tools (IDT; http:/idtdna.com/Scitools/Applications/Primerquest). Amplicon sequence identity was confirmed with NCBI Basic Local Alignment Search Tools software (Blast, http://blast.ncbi.nlm.nih.gov/Blast.cgi). The qPCR products identities were confirmed by sequencing and by agarose gel electrophoresis for all target genes. Primers were synthesized by Invitrogen (Life Technologies, São Paulo, SP, Brazil) and details are provided on Table 1.

In order to select reference genes, analysis of gene expression stability (M) (VANDESOMPELE et al., 2002) was achieved using qBasePLUS software v. 2.3 (Biogazelle, Zwijnaarde, Belgium) based on the geNorm application. Glyceraldehyde3-Phosphate Dehydrogenase (GAPDH), Actin Beta (ACTB), Cyclophilin A (PPIA), Ribosomal Protein L15 (RPL15) and Ribosomal Protein S18 (RPS18) Ct values were converted to scale expression quantities using the delta-Ct method and entered into geNorm. Genes were ranked based on $\mathrm{M}$ values, where the genes with the most stable expression had the lowest values. Data was analyzed in geNorm initially using all five genes and then the four most stable genes (PPIA, GAPDH, ACTB and RPS18) were selected.

Real-Time qPCR was carried out in 96-well plates sealed with MicroAmp optical adhesive cover (Life Technologies) using the Step One Plus apparatus (Applied Biosystem Real-Time PCR System; Life Technologies). Reactions were conducted in a final volume of $20 \mu \mathrm{L}$ using $10 \mu \mathrm{L}$ of Power SYBR Green PCR Master Mix (Life Technologies), $4 \mu \mathrm{L}$ of cDNA (diluted 1:80) and $6 \mu \mathrm{L}$ of specific forward and 
reverse primers. The PCR program consisted of an initial denaturation step at $95{ }^{\circ} \mathrm{C}$ for 10 min, followed by 40 cycles of 15 seconds at $95^{\circ} \mathrm{C}$ and annealing at $60{ }^{\circ} \mathrm{C}$ for 1 min. After each qPCR reaction, melting curves were obtained by stepwise increases in the temperature from 60 to $95^{\circ} \mathrm{C}$ to ensure single-product amplification. Serial dilutions of the appropriate cDNA were used as standard curves and efficiencies were between 90 and 105\% for all genes validated (based in slope values). Expression was determined in triplicate with relative quantification by linear regression of fluorescence data. Cycle quantification $(\mathrm{Cq})$ values per sample were obtained from the LinRegPCR software (V2014.2; http://linregpcr.nl/). Cq ratios of individual targets and reference genes were calculated using the Pfaffl mathematical model (Pfaffl, 2001). Quantification was obtained after normalization of the target genes expression values ( $\mathrm{Cq}$ values) by the geometric mean of PPIA, GAPDH, ACTB and RPS18 expression values. 


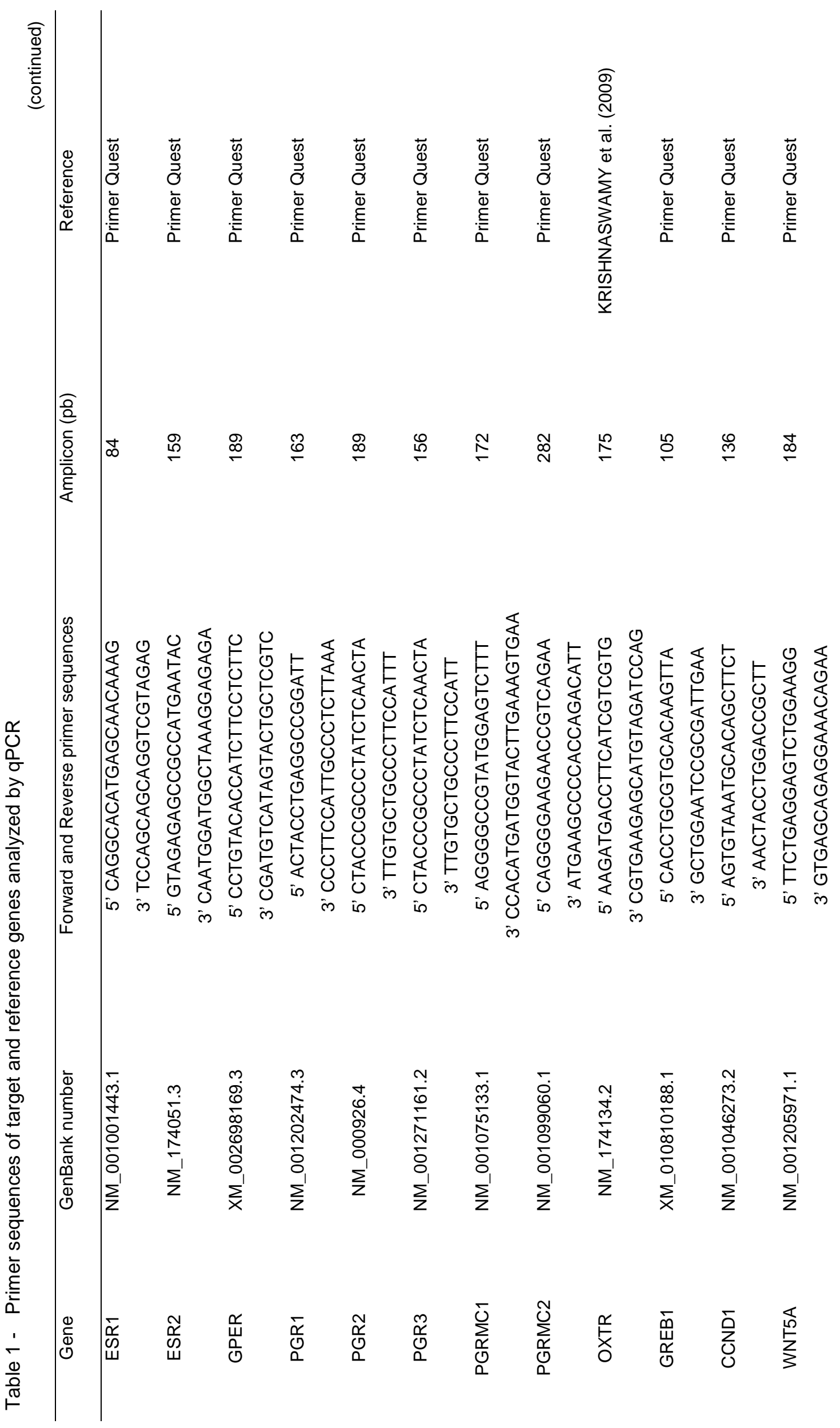




\subsubsection{Immunohistochemistry}

Paraffin-embedded samples were stained with antibodies against PGR and ERa to determine the tissue response pattern to endocrine profiles. Sections $(5 \mu \mathrm{m})$ were mounted onto a silanized slide (Star Frost, Knittel Glass, Braunschweig, Germany), deparaffinized in xylene and rehydrated in a series of increasing dilutions of ethanol. Sections were incubated for $5 \mathrm{~min}$ in $10 \mathrm{nM}$ citrate buffer $(\mathrm{pH} 6)$ at room temperature, and then processed for 4 cycles of $5 \mathrm{~min}$ in a microwave for antigen retrieval. Next, slides were cooled at room temperature for $20 \mathrm{~min}$ and washed in PBS containing $0.3 \%$ Triton (PBS-Triton; pH 7.4). Endogenous peroxidase activity was blocked by incubation in $1.5 \%$ hydrogen peroxide in methanol for $30 \mathrm{~min}$ at room temperature and Coverplate $^{\mathrm{TM}}$ (Thermo Fisher Scientific, Waltham, MA, USA) technology was subsequently used. Between each step, tissue sections were washed in PBS-Triton.

To block nonspecific binding, protein block was carried out using 2\% BSA (A8806; Sigma-Aldrich, Saint Louis, MO, USA) solution for $30 \mathrm{~min}$ at room temperature. Tissue sections were incubated with a solution of mouse monoclonal anti-Progesterone Receptor (PGR) primary antibody (Clone 160 PR10A9; 1:100 dilution; Beckman Coulter PN IM1546; France) overnight at $4{ }^{\circ} \mathrm{C}$ or anti-Estrogen Receptor alpha mouse monoclonal (Clone 1D5; $1: 50$ dilution; Dako, Denmark) for 60 $\mathrm{min}$ at room temperature. For the negative control, serum IgG from the same species in which primary antibody was raised, at the same respective dilution. The Biotinylated Link Universal Solution (DK0690, Dako) was used as secondary antibody, and was incubated for $15 \mathrm{~min}$ at room temperature. Slides were incubated with a streptavidin-peroxidase complex (Streptavidin-HRP, K0690, DAKO) for $15 \mathrm{~min}$. Then, microscope slides were removed from coverplates. Sections were then incubated in 3,3'-diaminobenzidine tetrachloride (DAB, K3468, DAKO) solution for 5 min and washed in distilled water. Finally, samples were counterstained with hematoxylin, washed in running tap water for $10 \mathrm{~min}$, dehydrated in ethanol gradient solutions and cleared in xylene prior to mounting with a coverslips. The immunostaining procedure for each primary antibody was performed in a single run for all samples. Digital images were captured using a Zeiss Axioplan 2 Microscope (Carl Zeiss, Thornwood, NY, USA) with an Axiocam HR digital color camera. 
The immunostaining procedure for each protein was performed on samples from 5 animals per group and replicated in two slides per animal. Staining intensity was scored on a 4-point scale (i.e., absent, 0; positive but weak, 1; moderate, 2; intense, 3) for luminal epithelium (LE), glandular epithelium (GE) and stroma cells (SC).

\subsubsection{Alcian blue stain for transmembrane mucin}

Alcian Blue ( $\mathrm{pH}$ 2.5; mucin stain) was used for visualization of sulfated and carboxylated acid mucopolysaccharides and sulfated and carboxylated sialomucins. Briefly, paraffin-embedded D7 endometrial samples (sections of $2 \mu \mathrm{m}$ ) were mounted on slides (Star Frost, Knittel Glass), deparaffinized in xylene, hydrated and subsequently incubated in Alcian Blue solution ( $\mathrm{pH} \mathrm{1.0,} \mathrm{Fr} \mathrm{100T)} \mathrm{for} 40$ min at room temperature. Subsequently, samples were incubated in Chloric Acid for 2 min and washed in running tap water for 1 min. Safranin $O$ (Biogenex, Hangue, Netherlands) was used as counterstain. Samples were washed in running tap water to remove excess dye, dehydrated in ethanol gradient solutions and cleared in xylene prior to mounting with a coverslip. Duodenal and pancreatic tissues were respectively included as positive and negative controls. The staining procedures for all endometrial, negative and positive control samples were performed in a single run.

Digital images were captured at 400x magnification using a Zeiss Axioplan 2 Microscope (Carl Zeiss, Thornwood, NY) with an Axiocam HR digital color camera. A semi-quantitative evaluation of transmembrane mucin signal intensity was performed blindly by three observers.

\subsubsection{Statistical Analysis}

Numbers of cows contributing to each variable analyzed are indicated in the relevant tables and figures. Cow was the experimental unit in all models. The Shapiro-Wilk test was used to test normality of residuals. Levene's test was used to 
check the homogeneity of variances. For each dependent variable, data that were not normally distributed were transformed to natural logarithms or inverse. Discrete dependent variables were analyzed for the main effect of group (LF-LCL vs SF-SCL) by the one-way ANOVA using the GLM procedure (SAS 9.2). Pearson's coefficient of correlation between ovarian parameters, hormonal concentrations and mRNA abundance was also calculated.

All data were expressed as means \pm standard error of the mean ( \pm S.E.M.). Treatment differences with $\mathrm{P} \leq 0.05$ were considered significant and probability of $0.05<\mathrm{P} \leq 0.10$ were designated as a tendency. 


\section{RESULTS}

\subsection{OVARIAN AND ENDOCRINE VARIABLES}

Hormonal manipulations successfully generated distinct groups of animals, presented contrasting ovarian morphology and sex steroid endocrine profiles as published previously by our group (MESQUITA et al., 2014). In Experiment 1, for the POF diameter, a group effect was detected $(P<0.01)$ and the average POF diameter was 1.4 fold greater in LF-LCL group than in SF-SCL group (Table 2). In agreement with these findings, E2 plasma concentrations on D0 were increased $(P<0.01) 2.8$ fold in LF-LCL group. Pearson's coefficient of correlation between POF diameter and E2 concentration on D0 was high $(r=0.86$; $P<0.001)$. Regarding the $C L$ values at D4, LF-LCL animals had a CL weight 1.5 fold greater $(P<0.01)$, and had greater concentrations of P4 (1.8 fold; $\mathrm{P}<0.01$ ). Furthermore, on D4, CL blood flow and diameter of the largest follicle from the first wave were similar between treatments.

Similarly, in Experiment 2 (Table 3), cows from the LF-LCL group developed larger POF (1.4 fold, $\mathrm{P}<0.01)$ and had greater circulating concentrations of $\mathrm{E} 2$ on D0 (2.3 fold; $P<0.01$ ). As expected, LF-LCL animals developed larger CLs (1.8 fold; $P<0.01)$ and had plasma $P 4$ concentrations 1.7 times greater $(P<0.01)$ than $S F-$ SCL animals on D7. Diameter of the largest follicle from the first wave on D7 was similar between treatments. 
Table 2 - Pre-ovulatory follicle (POF), corpus luteum (CL), estradiol concentration (E2) and progesterone concentration (P4) measurements in cows with smaller POF and CL (SFSCL) or lager POF and CL (LF-LCL) in Experiment 1. Values are expressed as means \pm SEM

\begin{tabular}{llll}
\hline \multirow{2}{*}{ Parameter } & \multicolumn{2}{c}{ Group } & \\
\cline { 2 - 3 } & SF-SCL $(\mathbf{n = 8})$ & LF-LCL $(\mathbf{n}=\mathbf{8})$ & P $>$ F \\
\hline Pre-ovulatory follicle diameter $(\mathrm{mm})$ & $11.32 \pm 0.24$ & $15.99 \pm 0.33$ & $<0.0001$ \\
Plasma E2 concentrations on D0 $(\mathrm{pg} / \mathrm{mL})^{\mathrm{a}}$ & $1.09 \pm 0.18$ & $3.16 \pm 0.36$ & $<0.01$ \\
CL area on D4 $\left(\mathrm{mm}^{2}\right)^{\mathrm{b}}$ & $1.02 \pm 0.09$ & $1.39 \pm 0.08$ & $<0.01$ \\
CL blood flow $(\%)^{\mathrm{c}}$ & $36.25 \pm 4.12$ & $43.75 \pm 3.83$ & 0.42 \\
CL Weight $(\mathrm{g})^{\mathrm{d}}$ & $0.69 \pm 0.03$ & $1.06 \pm 0.03$ & $<0.01$ \\
Plasma P4 concentrations on D4 $(\mathrm{ng} / \mathrm{mL})$ & $0.80 \pm 0.10$ & $1.40 \pm 0.23$ & $<0.01$ \\
${\text { Largest follicle diameter on D4 }(\mathrm{mm})^{\mathrm{e}}}$ & $9.20 \pm 0.30$ & $8.97 \pm 0.48$ & 0.68 \\
\hline
\end{tabular}

D0 is the day of $\mathrm{GnRH}$ treatment to induce ovulation.

${ }^{a}$ Estradiol concentration were assayed in a subset of animals ( $n=5-6 /$ group)

${ }^{\mathrm{b}}$ Measured by ultrasound

${ }^{c}$ Measured by pulsed-wave color Doppler ultrasound

${ }^{\mathrm{d}}$ Measured post mortem on D4

${ }^{\mathrm{e}}$ From the first wave

Table 3 - Pre-ovulatory follicle (POF), corpus luteum (CL), estradiol concentration (E2) and progesterone concentration (P4) measurements in cows with smaller POF and CL (SF$\mathrm{SCL}$ ) or lager POF and CL (LF-LCL) in Experiment 2. Values are expressed as means \pm SEM

\begin{tabular}{lccc}
\hline & \multicolumn{2}{c}{ Group } & \multirow{2}{*}{ P $>$ F } \\
\cline { 2 - 3 } Dependent Variable & SF-SCL $(\mathbf{n}=9)$ & LF-LCL $(\mathbf{n}=8)$ & $<0.0001$ \\
\hline Pre-ovulatory follicle diameter $(\mathrm{mm})$ & $9.82 \pm 0.38$ & $13.62 \pm 0.38$ & $<0.01$ \\
Plasma E2 concentrations on D0 $(\mathrm{pg} / \mathrm{mL})^{\mathrm{a}}$ & $0.93 \pm 0.16$ & $2.96 \pm 0.36$ & $<0.0001$ \\
CL Weight $(\mathrm{g})^{\mathrm{b}}$ & $1.53 \pm 0.16$ & $2.83 \pm 0.20$ & $<0.01$ \\
CL Volume $(\mathrm{cm})^{\mathrm{b}}$ & $1.58 \pm 0.24$ & $2.69 \pm 0.24$ & \\
Plasma P4 concentrations $(\mathrm{ng} / \mathrm{mL})$ & & & $<0.01$ \\
\multicolumn{1}{c}{ D7 } & $2.14 \pm 0.24$ & $3.68 \pm 0.38$ & $<0.01$ \\
$\quad$ Sum of D1 to D6 & $2.91 \pm 0.48$ & $7.34 \pm 1.08$ & 0.74 \\
\hline Largest follicle diameter on D7 $(\mathrm{mm})^{\mathrm{c}}$ & $11.39 \pm 0.43$ & $11.58 \pm 0.37$ &
\end{tabular}

D0 is the day of GnRH treatment to induce ovulation.

${ }^{a}$ Estradiol concentration were assayed in a subset of animals ( $n=5-6 /$ group)

${ }^{\mathrm{b}}$ Measured post mortem on D7

${ }^{\mathrm{c}}$ From the first wave 


\subsection{ENDOMETRIAL VARIABLES}

Endometrial transcripts data related to sections 4.2.1, 4.2.2 and 4.2.3 are demonstrated on Figures 3, 4 and 5.

\subsubsection{Effects of distinct pre-ovulatory endocrine profiles on endometrial transcripts at Do}

On D0, a greater $(\mathrm{P}<0.05)$ abundance of mRNA for ESR1 and all isoforms of nuclear P4 receptor (PGR1, PGR2 and PGR3) was observed in the endometrial tissue from LF-LCL cows. There was no significant difference $(P>0.1)$ between groups in the abundance of mRNA for ESR2, GPER, OXTR, PGRMC1 and PGRMC2 on D0. Abundance of mRNA for GREB1 $(P<0.05)$ and CCND1 $(P<0.05)$, both estrogen responsive genes involved in proliferation pathway in response to $\mathrm{E} 2$, was increased in the endometrium of cows from the LF-LCL group. Furthermore, abundance of mRNA for MMP2 was also greater $(P<0.05)$ in the endometrium of cows from LF-LCL group. The only estrogen responsive gene significantly downregulated in the LF-LCL group was SERPINA14 (10-fold lower, $\mathrm{P}<0.001$ ).

\subsubsection{Effects of distinct periovulatory endocrine profiles on endometrial transcripts at D4}

Amounts of mRNA for ESR1, ESR2 and GPER did not differ $(P>0.10)$ between groups on D4. In the LF-LCL treated cows, mRNA abundance for PGR1 and PGRMC2 were lower $(P<0.05)$ compared with counterparts. Transcript abundance for other genes encoding for P4 receptors did not differ with between groups.

Transcript abundance of target genes of steroid receptors were different between groups; OXTR $(P<0.001)$, FGF2a $(P<0.01), \operatorname{CCND1}(P<0.05)$ and 
MMP2 $(\mathrm{P}<0.05)$ were down-regulated in the LF-LCL animals. The AQP4 mRNA abundance was 2.4 -fold greater $(P<0.01)$ in $L F-L C L$ group. Interestingly, there was a strong correlation $(r=0.80 ; \mathrm{P}<0.01)$ between preovulatory E2 concentration on $\mathrm{D} 0$ and the amount of mRNA for AQP4 at D4.

\subsubsection{Effects of distinct periovulatory endocrine profiles on endometrial transcripts at D7}

Transcript abundance was greater $(P<0.005)$ for $E S R 2$ and lesser $(P<0.04)$ for PGR2 and PGR3 in the LF-LCL cows than SF-SCL counterparts. Abundance of mRNA for membrane $\mathrm{P} 4$ receptors (PGRMC1 and PGRMC2) was up-regulated $(\mathrm{P}<$ $0.01)$ in the LF-LCL group. An effect $(P<0.01)$ of group was detected for estrogen responsive genes studied and followed the same abundance direction for NRIP1, SERPINA14 and LTF transcripts. There was an increase in the expression of the secretory activity-related genes on LF-LCL group. In addition, abundance of transcripts for AQP4, related to uterine water movement, tended to be increased on LF-LCL group $(P=0.07)$. Abundance of mRNA for WNT5a, a target gene involved in proliferation, OXTR and MUC1 was down-regulated $(P<0.05)$ in the LF-LCL group. 
Figure 3 - Abundance of mRNA for steroid receptors normalized to cyclophilin A (PPIA), $\beta$-Actin $(A C T B)$, ribosomal protein $S 18$ (RPS18) and glyceraldehyde-3-phosphate dehydrogenase $(G A P D H)$ in endometrium from beef cows synchronized to ovulate a large (LF-LCL) or small follicle (SF-SCL) on day of GnRH treatment (D0), four (D4) or seven (D7) days later. Significant differences $(P<0.05)$ between treatments is indicated. Genes: estrogen receptor $\alpha$ (ESR1), estrogen receptor $\beta$ (ESR2), G protein-coupled estrogen receptor (GPER), progesterone receptor isoform A (PGR1), isoform (PGR2) and isoform C (PGR3), progesterone receptor membrane component 1 (PGRMC1) and 2 (PGRMC2)
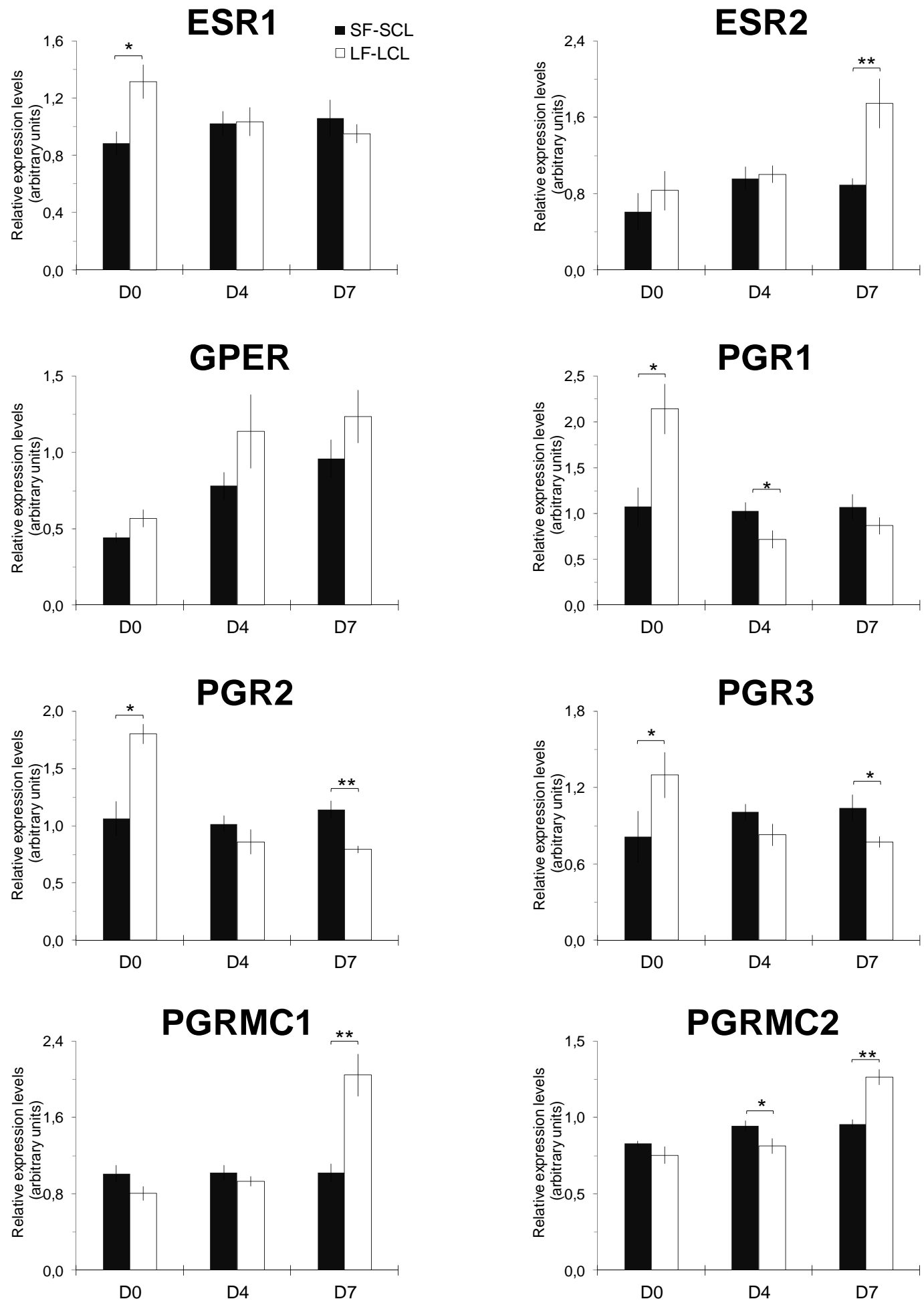

(Fonte: SPONCHIADO, M., 2015) 
Figure 4 - Abundance of mRNA for estrogen responsive genes normalized to cyclophilin A (PPIA), $\beta$ Actin (ACTB), ribosomal protein S18 (RPS18) and glyceraldehyde-3-phosphate dehydrogenase $(G A P D H)$ in endometrium from beef cows synchronized to ovulate a large (LF-LCL) or small follicle (SF-SCL) on day of GnRH treatment (D0), four (D4) or seven (D7) days later. Significant differences $(P<0.05)$ between treatments is indicated. Genes: growth regulation by estrogen in breast cancer 1 (GREB1); cyclin D1 (CCND1); wingless-type MMTV integration site family, member 5A (WNT5A); fibroblast growth factor 2 (FGF2); matrix metallopeptidase 2 (MMP2) and nuclear receptor interacting protein 1 (NRIP1)
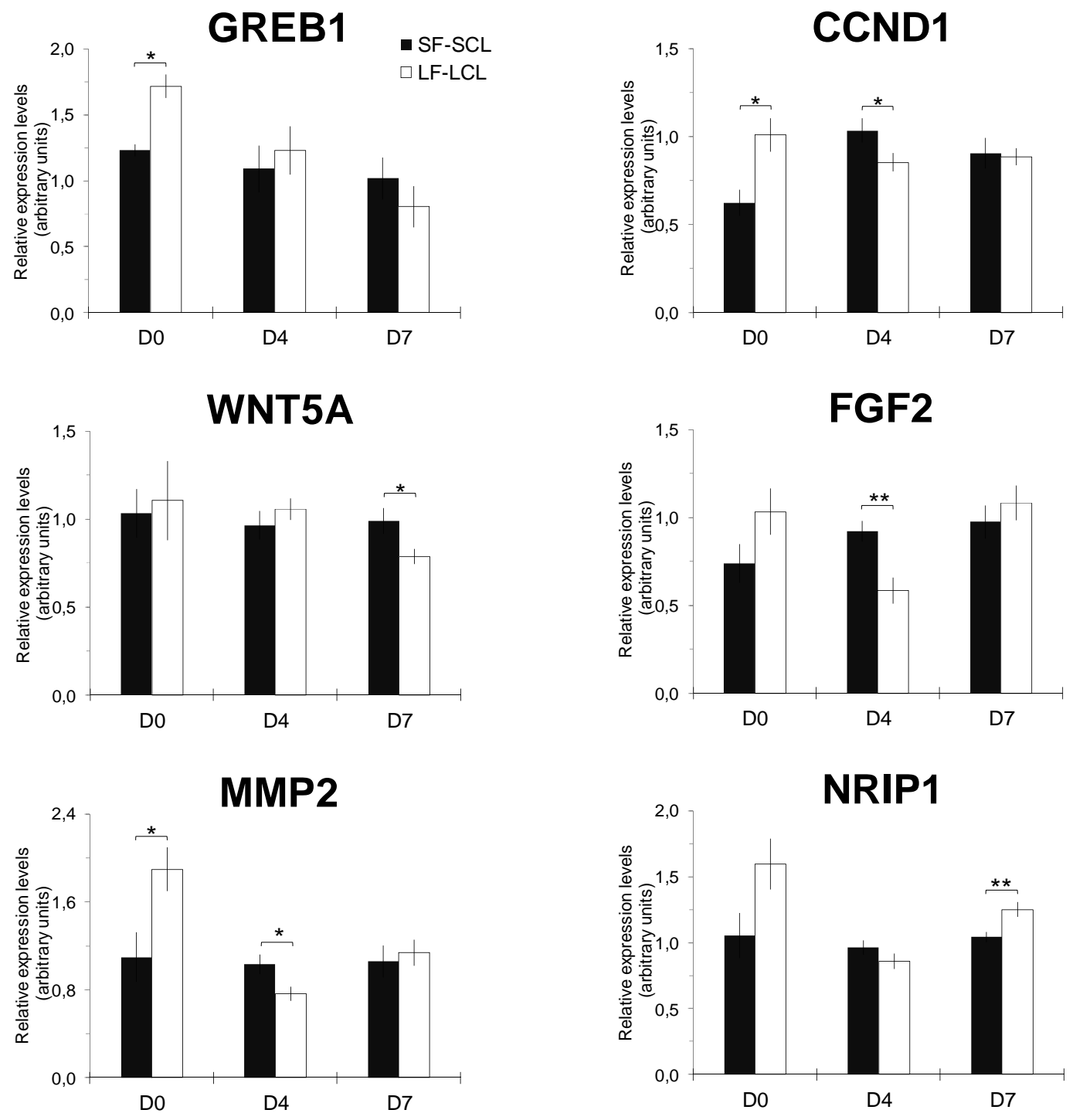

(Fonte: SPONCHIADO, M., 2015) 
Figure 5 - Abundance of mRNA for estrogen responsive genes normalized to cyclophilin A (PPIA), $\beta$ Actin (ACTB), ribosomal protein S18 (RPS18) and glyceraldehyde-3-phosphate dehydrogenase $(G A P D H)$ in endometrium from beef cows synchronized to ovulate a large (LF-LCL) or small follicle (SF-SCL) on day of GnRH treatment (D0), four (D4) or seven (D7) days later. Significant differences $(P<0.05)$ between treatments is indicated. Genes: aquaporin $4(A Q P 4)$; lactotransferrin ( $L T F)$; serpin peptidase inhibitor, clade A member 14 (SERPINA14), mucin 1 cell surface associated (MUC1) and oxytocin receptor (OXTR)
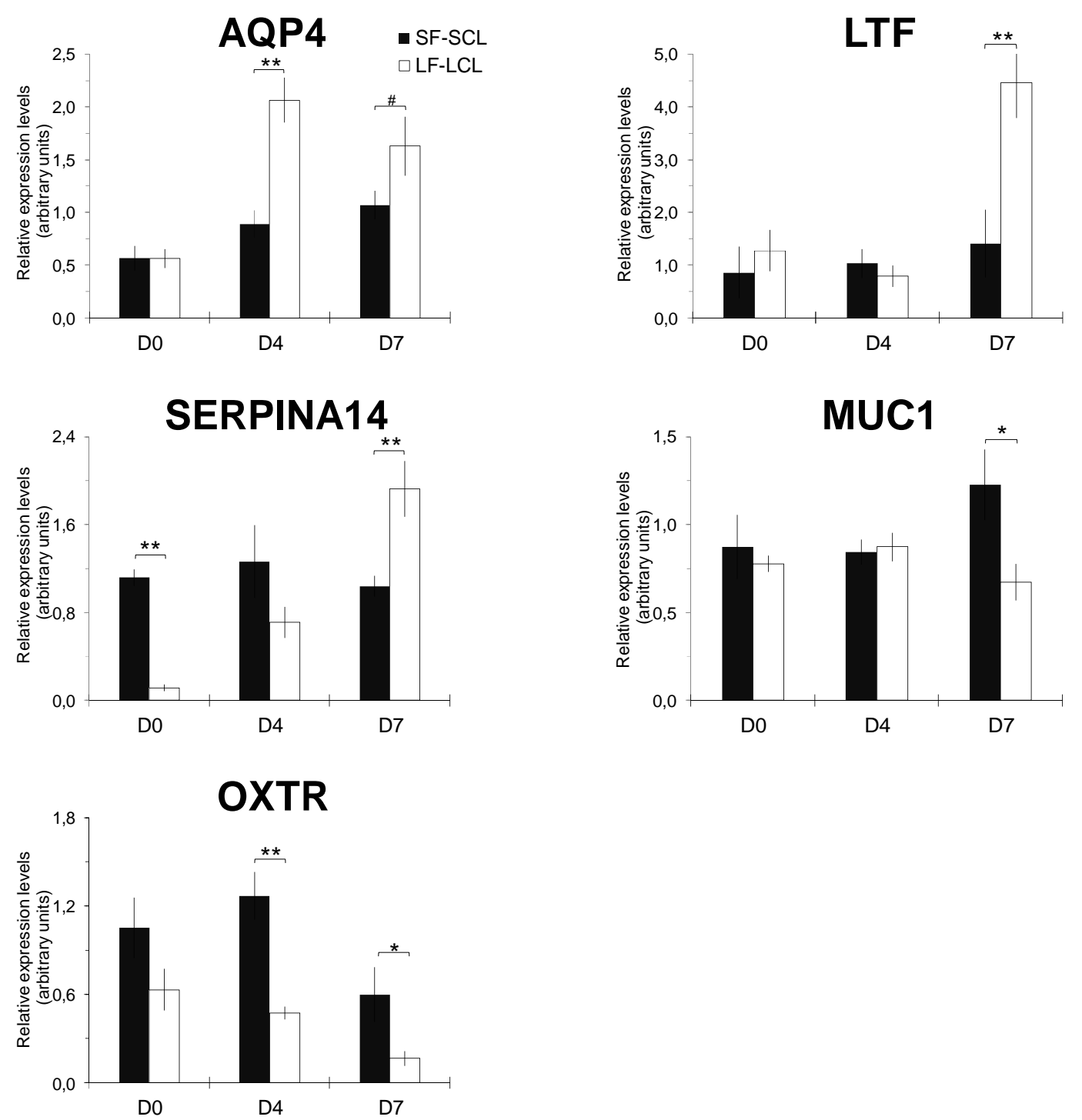

(Fonte: SPONCHIADO, M., 2015) 


\subsubsection{Protein localization}

Immunostaining for ERa (Figure 6) and PGR (Figure 7) in endometrial cross sections was predominantly nuclear. When nonimmune mouse $\lg G$ replaced for the primary antibody, the absence of staining demonstrated the high specificity of ERa and PGR immunoreactivity. Immunostaining within endometrial cell compartments was graded on a scale of absente (0) to intense (3). ERa immunopositive staining was detected in all cellular compartments in both groups on D4 endometrial samples. In the LF-LCL cows, ERa immunostaining ranged from weak (in the LE and SC) to intense (in the GE), while it was moderate in GE cellular compartment in SF-SCL samples on D4. PGR immunostaining was detected in all cellular compartments on endometrial samples from $\mathrm{D} 4$, ranging from moderate (in the LE and $\mathrm{SC}$ ) to intense (in the GE) in both groups.

On D7, Immunolocalization for ERa (Figure 6; Panel C and D) in the LF-LCL samples ranged from absent (in the LE) to weak (in the SC) to intense (in the GE), while it was weak (in the LE and SC) to moderate (in the SGE) in SF-SCL samples. Protein localization for PGR (Figure 7; Panel $C$ and D) demonstrated that immunostaining ranged from weak (in the $\mathrm{SC}$ ) to moderate (in the GE) to intense (in the LE) in LF-LCL samples, while positive staining was absent on SC in SF-SCL samples from $\mathrm{D} 7$. 
Figure 6 - Localization of nuclear estrogen receptor alpha $(E R \alpha)$ in bovine endometrium collected on D4 (Experiment 1; SF-SCL panel A, LF-LCL panel B) and D7 (Experiment 2; SF-SCL panel C, LF-LCL panel D) of cows with larger (LF-LCL group) or smaller (SF-SCL) pre-ovulatory follicle and corpus luteum. No immunopositive staining was detected when primary antibody was replaced by mouse IgG (Negative control, panel E and F). Representative images of PGR protein immunolocalization in luminal epithelium (LE), glandular epithelium (GE), and stroma cells (SC). Original magnification 200x

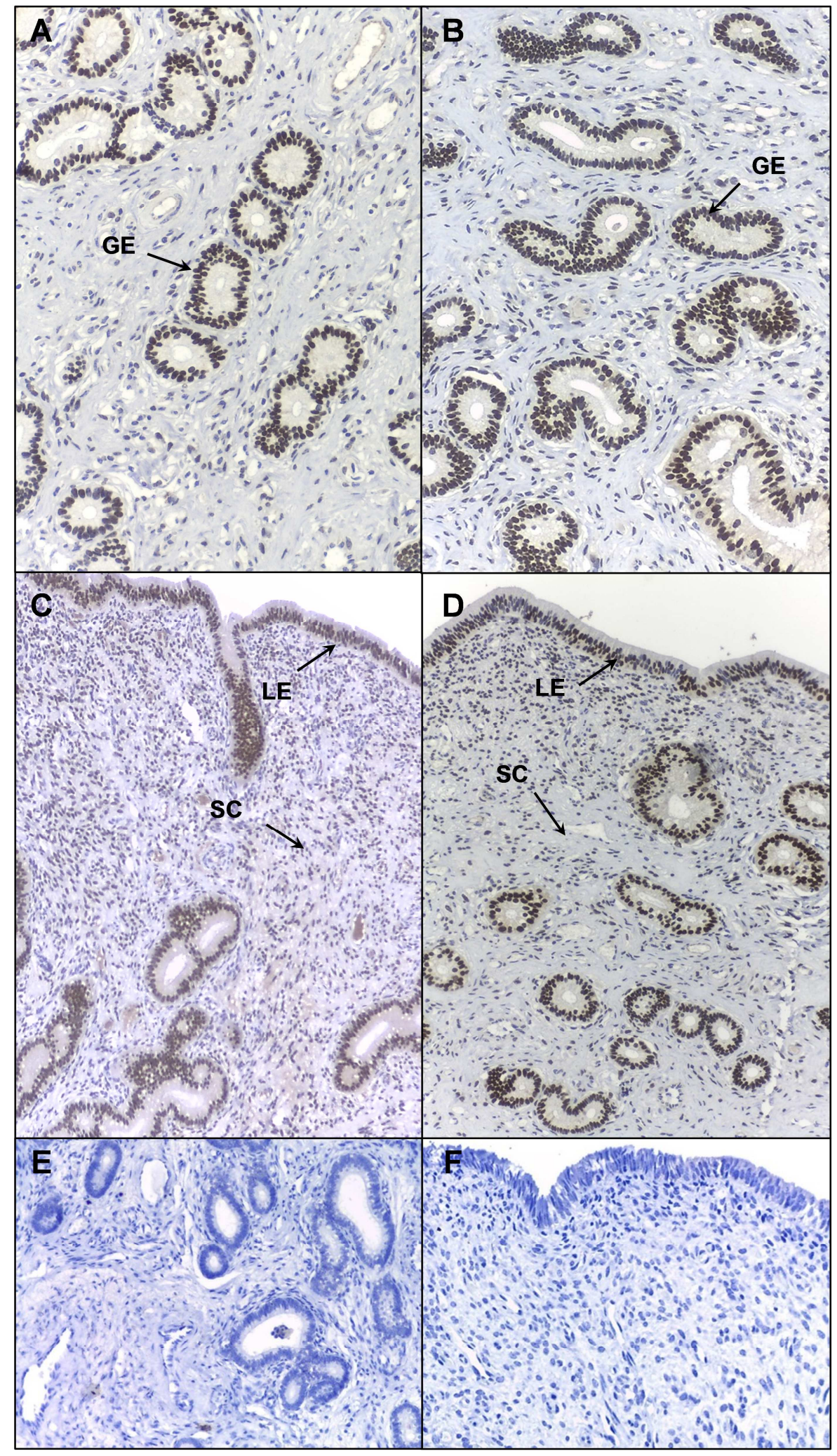

Fonte: (SPONCHIADO, M., 2015) 
Figure 7 - Localization of nuclear progesterone receptor (PGR) in bovine endometrium collected on D4 (Experiment 1; SF-SCL panel A, LF-LCL panel B) and D7 (Experiment 2; SF-SCL panel C, LF-LCL panel D) of cows with larger (LF-LCL group) or smaller (SF-SCL) pre-ovulatory follicle and corpus luteum. No immunopositive staining was detected when primary antibody was replaced by mouse IgG (Negative control, panel $E$ and F). Representative images of PGR protein immunolocalization in luminal epithelium (LE), glandular epithelium (GE), and stroma cells (SC). Original magnification 200x

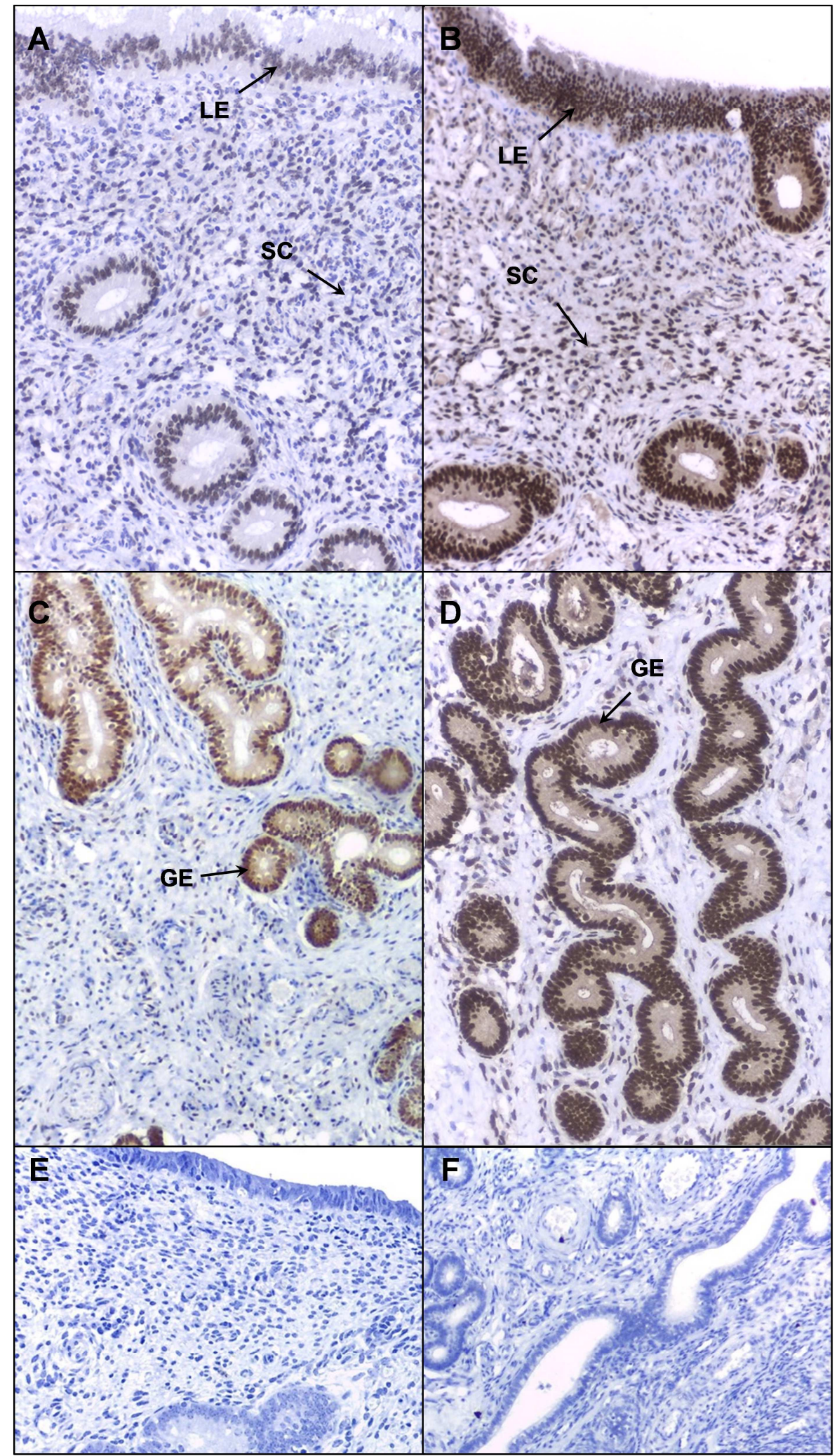

Fonte: (SPONCHIADO, M., 2015) 


\subsubsection{Steroid modulation of Mucin abundance in the endometrial epithelium}

Analysis was undertaken to determine whether glycoproteins pattern changed in endometrial glandular epithelium and lumen under different periovulatory endocrine profiles. Paraffin embedded endometrial samples ( $n=6 /$ group) were stained with Alcian Blue for semiquantitative analyses of mucin staining intensity. Quantitative PCR data showed that endometrial MUC1 gene expression was reduced (1.83-fold) in LF-LCL tissue $(P<0.05)$ at D7. Histology of endometrial samples revealed that the signal for transmembrane, anti-adhesive, mucin at the LFLCL epithelium was consistently low when compared to SF-SCL tissue (33.3\% vs. $62.0 \%$ ) at D7 (Figure 8). SF-SCL tissue group displayed variable amounts of transmembrane mucin at the apical epithelial boarder.

Figure 8 - Visualization of sulfated and carboxylated acid mucopolysaccharides and sulfated and carboxylated sialomucins in bovine endometrium collected on D7 (Experiment 2) using Alcian Blue Stain. Duodenal sections were used as positive (Panel E) control. Representative images of mucins staining in glandular epithelium (GE; Panel $A$ and $B$ ) and luminal epithelium (LE, Panel C and D) in the SF-SCL (Panel A and C) and LF-LCL (Panel $B$ and D) groups. Original magnification 400x

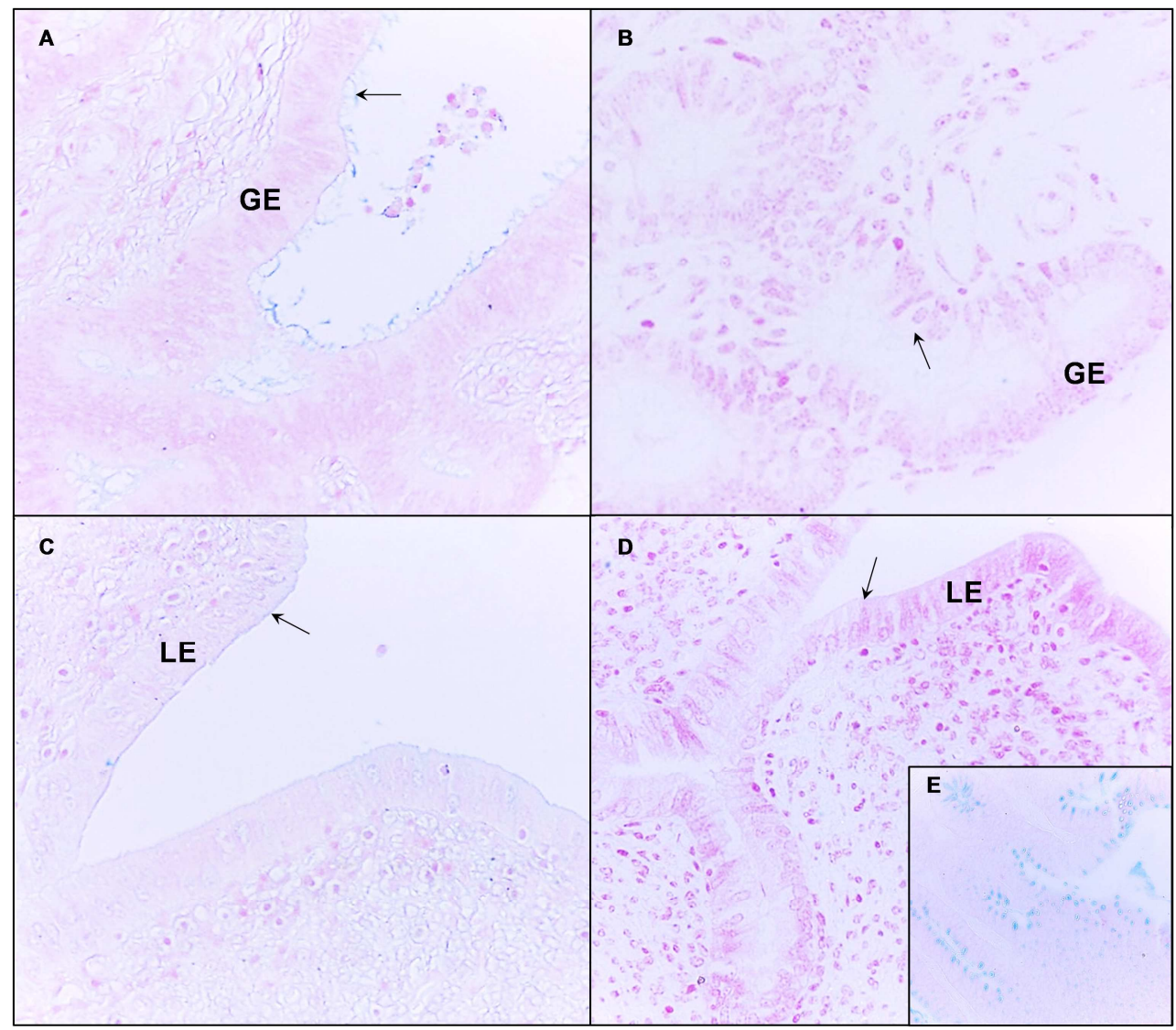

Fonte: (SPONCHIADO, M., 2015) 


\section{DISCUSSION}

Previous studies from our laboratory consistently showed that such manipulation of the periovulatory fluctuations of E2 and P4 concentrations, within physiological limits, alter the abundance and activity of endometrium-derived molecules (i.e., transcripts, proteins and metabolites) that are potentially involved in the control of uterine receptivity and fertility (MESQUITA et al., 2014; RAMOS et al., 2014; FRANÇA et al., 2015; RAMOS et al., 2015; MESQUITA et al., 2015, in press). As anticipated and previously demonstrated (MESQUITA et al., 2014), the experimental model used in the present study resulted in two treatment groups that differed in POF diameter and E2 concentrations, by inducing ovulation with GnRH after a long (2.5 days; LF-LCL group) or short (1.5 days; SF-SCL group) period of proestrus. Consequently, peripheral E2 (proestrus-estrus) and P4 concentrations (early diestrus) differed between treatments in both experiments. Besides different hormonal profiles, transcript abundance of sex steroid receptor and target genes was also affected by treatments. Moreover, changes were specific to the day analyzed. The combination of endocrine and endometrial molecular profiles characterizes the sex steroid tone of estrus and early diestrus in response to treatments.

On D0, sex steroid tone was limited to the effects of E2 and its receptors. Thus, changes in the expression of target genes associated with treatments are probably due to changes in abundance of these players. The greater concentrations of E2 and abundance of transcripts for ESR1 on the LF-LCL group suggests a greater E2 tone in this group, and this reflected on greater abundance of E2 target transcripts. Target transcripts include those coding for sex steroid receptors, genes associated with proliferation and extra cellular matrix remodeling. Here, abundance of transcripts for ESR1, PGR1, PGR2 and PGR3 was positively regulated by E2 as reported earlier (HORWITZ; MCGUIRE, 1978; SPENCER; BAZER, 1995; ROBINSON et al., 2001). It is proposed that preovulatory E2 via ERa can enhance endometrial responsiveness to E2 and $\mathrm{P} 4$ along the early luteal phase, in agreement with previous findings in cattle (ROBINSON et al., 2001) and ewe (SPENCER; BAZER, 1995). Regarding the recognized proliferative role of estrogens in the female reproductive tract, it appears that ERa mediates the major proliferative effects of E2 
(WANG et al., 1999). One important target gene through which estrogen-complexed ERa mediates its proliferative action in the endometrium is cyclin D1 (CCND1), a major regulator of entry into the proliferative stage of the cell cycle. In the present study, abundance of mRNA for CCND1 was greater in the LF-LCL group. Another gene involved in E2-induced endometrial proliferation is GREB1. Pellegrini et al. (2012) demonstrated that GREB1 plays an important role in the estrogen-dependent proliferation of breast and endometrial cells. GREB1 contains three ERE sequences in its enhancer region and ERa protein binds two ERE sequences in the 5'-flanking region of the GREB1 gene. Collectively, it seems reasonable to assume that E2 tone on D0 stimulates endometrial proliferation on the LF-LCL.

The extra cellular matrix (ECM) interacts with cells in order to both provide mechanical support and molecular information necessary for the regulation of many processes vital to the cell, such as adhesion and migration, proliferation, angiogenesis, among others. There is an acute remodelling of the endometrial ECM at estrus. Mitko et al. (2008) evaluated the dynamic changes mRNA profiles of bovine endometrium during the estrus cycle, and a number of mRNAs coding for the ECM proteins was found enriched at ovulation, indicating that remodeling of the ECM in the endometrium is an enriched biological process in response to E2. Expression of MMP2 mRNAs coding for proteases is involved in the ECM degradation. In the present study, the greater amount of MMP2 mRNA in the LF-LCL group points to a greater ECM remodeling activity in this group during the proestrus-estrus period.

On D4, the sex steroid tone presented both E2 and P4 components. E2 concentrations on day 4 were not measured in the present experiment, but first wave dominant follicle sizes were similar between groups. Because of the strong association between follicle size and peripheral E2 concentrations, it is reasonable to assume that the later were similar between groups. Thus, the E2 tone was mostly dependent on receptor abundance. In contrast, P4 tone was probably associated with a combination of P4 circulating concentrations and PGR tissue abundance.

On D4, abundance of transcripts for sex steroid receptors was similar between groups, except for PGR1, that was reduced in the LF-LCL cows. Down-regulation was probably associated with the greater rise of peripheral P4 in the LF-LCL group, as reported for later diestrus (SPENCER; BAZER, 1995). Despite the lack of regulation of ERs transcript abundance on this day, expression of estrogenresponsive genes was different between groups. Expression of two proliferation- 
associated genes, FGF2 and CCND1, and that of MMP2 and OXTR, was down regulated in LF-LCL endometrial tissue. Accordingly, there was a strong and negative correlation between FGF2 ( $r=-0.66$; $\mathrm{P}<0.01)$, CCND1 $(r=-0.91 ; \mathrm{P}<0.001)$, MMP2 $(r=-0.57 ; \mathrm{P}<0.05)$, OXTR $(r=-69 ; \mathrm{P}<0.01)$ transcripts and POF diameter. Another E2-responsive gene that was upregulated in the LF-LCL group was AQP4. Indeed, mRNA abundance was 2.4-fold greater in LF-LCL group and there was a strong correlation $(r=0.80 ; P<0.01)$ between preovulatory E2 concentration and the amount of mRNA for AQP4 at D4. Aquaporins (AQP) are a family of small integral plasma membrane proteins that primary are responsible by the rapid and specific water flow water across the plasma membrane. Specifically, AQP4 is a classical aquaporins subgroup member, expressed in the female reproductive tract and their diverse functions include not only water transport in fluid secretion and fluid absorption, serves also as a gas channel for NO and O2 (ZHU et al., 2014). The movement of water through the aquaporin channel is driven by osmotic gradients. Transport and homeostasis of water in the female reproductive system, especially in endometrium, is crucial for maintaining normal reproductive performance, as well as fetal growth and development. Estrogen is reported as a regulate AQP4 expression in the female reproductive tract (JABLONSKI et al., 2003). Thus, physiological concentrations of estrogen stimulate water imbibition in the uterine endometrium and increase water permeability of luminal epithelial cells. This allows for an increased amount of water to cross the epithelial cells into the lumen, leading to a decrease in viscosity of uterine luminal fluid and uterine preparation for implantation of the blastocyst. Reasons for the differential expression of E2-responsive genes under apparent similar E2 tones can only be speculated. It is possible that different E2 tones between groups that existed before D4 elicited changes in the target genes abundance that endured until D4. Alternatively, the similar concentrations of transcripts for ESR1 may have not been reflected by protein concentrations of ERs, as the regulation of steady state abundance of sex steroid mRNAs and proteins are not necessarily homogeneous (ULBRICH; KETTLER; EINSPANIER, 2003). Yet another explanation is that regulation of expression is not solely through E2. Indeed, using a ovariectomized, steroid-supplemented cow model, Shimizu et al. (2010) demonstrated that AQP4 mRNA is downregulated by E2 and upregulated by P4 treatment in bovine endometrium. Collectively, similar to D0, target gene differential expression suggests a possible role of preovulatory E2 in the regulation of 
proliferation and extracellular matrix remodeling on early diestrus. Indeed, Mesquita et al. $(2015 \text {, in press })^{7}$ using the same animal model used here, reported that the proportion of proliferating cells in the stroma, glandular epithelium and luminal epithelium was greater in the endometrium of cows from the LF-LCL group on D4.

On D7 the factors associated with the sex steroid tone were the same listed for D4: based on dominant follicle size, E2 concentrations were probably similar between groups, while P4 concentrations were contrasting; differences in ER and PGR associated with corresponding ligands probably determined tissue responsiveness.

Regarding the E2 tone, only the abundance of ESR2 differed between groups on D7, and this was associated positively with P4 concentration in the same day ( $r=$ 0.81 ; $P<0.001$ ), suggesting a potential effect of the early diestrus endocrine milieu on the uterine responsiveness to E2 via ERß. Okumu et al. (2010) suggested that in cattle, ER $\beta$ may be responsive to the stimulatory effects of E2 from non-ovulatory follicles, such as the first wave follicle present in the present study. Antiproliferative effect of ER $\beta$ might be necessary to protect from estrogen action from this follicle on diestrus. This is because in this period, the endometrial tissue must be refractory to the proliferative stimulus of E2. Pronounced changes on the expression of P4 receptor expression indicate a modulation of the P4 tone on D7. Here, we have demonstrated for the first time that elevated P4 from days 3-7 of the estrous cycle advances the downregulation of the nuclear PGR isoforms, at the transcriptional level. Decrease on abundance of mRNA for PGR1 and PGR3 isoforms on LF-LCL group may indicate the beginning of the down-regulation effect of $\mathrm{P} 4$ on its receptors, since this group was exposed to greater $\mathrm{P} 4$ concentrations on diestrus. Silencing of PGRs and ERa in the endometrial epithelia is a prerequisite for implantation, since it allows expression of genes related to secretory proteins, and selective transport of molecules into the uterine lumen to create histotroph that is essential for conceptus growth and development (SPENCER; BAZER, 1995). Differential expression of genes by uterine epithelia and stromal cells in response to $\mathrm{P} 4$ is considered essential for successful embryo implantation in most mammals. Therefore, there is a paradox

\footnotetext{
7 MESQUitA, F. S.; RAMOS, R. S.; PUGLIESI, G.; ANDRADE, S. C. S.; VAN HOECK, V.; LANGBEEN, A.; OLIVEIRA, M. L.; GONELLA-DIAZA, A. M.; GASPARIN, G.; FUKUMASU, H.; PULZ, L. H.; MEMBRIVE, C. M. B.; COUTINHO, L. L.; BINELLI, M. The receptive endometrial transcriptomic signature indicates an earlier shift from proliferation to metabolism at early diestrus in the cow. Biology of Reproduction (in press), 2015.
} 
between the increase of P4 concentration and the loss of its cellular mediators in the endometrium. It seems reasonable to assume that not all actions of P4 are mediated by its nuclear receptors. Indeed, recent studies have reported that P4 can also affect cell response though membrane receptors with P4 binding activity, referred as progesterone receptor membrane component (PGRMC) 1 and 2 (LÖSEL et al., 2008; GELLERSEN; FERNANDES; BROSENS, 2009). This represents a via of fast action, because P4 can induce specific cell responses through nongenomic mechanisms. The presence of PGRMCs in the cow reproductive tissue have been documented by Luciano et al. (2011), but their roles are not well known. In the present study, the upregulation of $P G R M C 1$ and $P G R M C 2$ mRNA in animals that ovulated larger follicles and presented greater P4 concentrations after estrus indicate a possible enhanced endometrial responsiveness to P4 at D7 and, consequently, an important role for uterine receptivity. In addition, due to its positive correlation with preovulatory E2 $(r=$ 0.64 and $0.62 ; P<0.01)$ and $P 4$ concentrations at D7 $(r=0.75 ; P<0.01)$, we speculate that these receptors could be positively regulated by E2 and P4 or requires both P4 and E2 action, as suggested earlier (LUCIANO et al., 2011).

Bazer and Slayden (2008) suggested that the diestrus inhibition steroid receptors might trigger the expression of genes encoding secretory proteins and transporter molecules that selectively transfer substrates into the uterine lumen in order to produce histotroph. In the present study, the favorable peri-ovulatory endocrine milieu (higher E2 from proestrus-estrus and P4 on early diestrus) resulted indeed in an increased expression of the genes related to histotroph composition and conceptus maintenance (LTF; SERPINA14). LFT is an iron-binding glycoprotein secreted by epithelial cells, has a many functions including iron homeostasis and modulation of both the innate and adaptive immune systems (LEVAY; VILJOEN, 1995). Its functional role during early pregnancy of cows has not yet been elucidated; however, $L T F$ is well known estrogen-responsive gene in the mouse uterus (TENG, 1999) although P4 appears does not alter LTF expression (MCMASTER et al., 1992). Forde et al. (2010) displayed LTF localization in the uterine GE in cattle, indicates it may be secreted into the uterine lumen on days 5 and 7 of pregnancy or the estrous cycle to modulate immune cell functions.

Regarding SERPINA14 (previously known as UTMP, uterine milk protein), it is a major secretory protein expressed in the endometrium during pregnancy in ruminants (MOFFATT et al., 1987). Consistent reports show that SERPINA14 is 
secreted from the deep uterine glands into the lumen of ovine (ING et al., 1989) and bovine (ULBRICH et al., 2009) pregnant uterus. Its biological functions include direct nutrition to the conceptus, growth control, inhibition of proteolytic activities and suppression of the local maternal immune system for sustaining pregnancy. The present study demonstrate that SERPINA14 mRNA is regulated during the estrous cycle in response to hormonal profile in the bovine endometrium. Interestingly, SERPINA14 mRNA was 10-fold lower on LF-LCL (i. e. greater pre-ovulatory E2) group at D0, regarding this ratio was reversed at D7 (i. e. greater P4). Ulbrich et al. (2009), through a gene promoter region analysis, revealed that SERPINA14 have three half-sites for response to PGR and one for ER located close to the transcription start. A possible prerequisite for inducing ovine SERPINA14 might therefore be a reduction of PGR (SPENCER et al., 1999). Concentrations of SERPINA14 protein in cattle histotroph are increased after long exposure to P4 and, in the present study, there was a positive correlation between post-ovulatory P4 concentration and SERPINA14 mRNA abundance at D7 ( $\mathrm{r}=0.79 ; \mathrm{P}<0.01)$. In cows, greater expression of SERPINA14 in the uteri was associated with larger conceptuses on day 17 of pregnancy (LEDGARD; MEIER; PETERSON, 2011).

In domestic animals, embryo attachment involves direct interaction of the blastocyst with the luminal epithelium of the receptive uterus. MUC1, a transmembrane mucin expressed at the apical surface of uterine epithelia, acts as a barrier to microbial infection and enzymatic attack. Loss of MUC1 is believed to be a prerequisite for a functionally receptive uterus to permit access to appropriate receptors for embryo on the apical uterine epithelial cell surface (SURVEYOR et al., 1995; BOWEN; BAZER; BURGHARDT, 1997). Transcripts data revealed that cell surface MUC1 gene expression was drastically down-regulated in LF-LCL tissue compared to SF-SCL tissue on D7. Histology of endometrial samples revealed that the signal for transmembrane, anti-adhesive, mucin at the LF-LCL epithelium was consistently down-regulated when compared to SF-SCL counter-tissue. A downregulated expression of the transmembrane mucin might indicate be a favorable condition facilitating endometrial receptivity. 


\section{CONCLUSIONS}

In conclusion, the periovulatory sex steroid tone lead to differential expression of steroid responsive genes on endometrium in a time specific manner. Reported data, at transcriptional level, suggest that the endometrial tissue from LF-LCL cows experienced a greater proliferative activity (D0) and greater secretory activity (D7) compared with SF-SCL group, which potentially improve early embryo development and consequently the conception. Future studies are necessary to investigate specific pathways in detail. This implies that the model used in the present study might provide a useful tool to modulate and fine-tune, within physiological limits, the uterine receptive environment at D7. 


\section{REFERÊNCIAS}

BAZER, F. W.; SLAYDEN, O. D. Progesterone-induced gene expression in uterine epithelia: a myth perpetuated by conventional wisdom. Biology of Reproduction, $v$. 79, p. 1008-1009, 2008.

BAZER, F. W.; WU, G.; JOHNSON, G. A.; KIM, J.; SONG, G. Uterine histotroph and conceptus development: select nutrients and secreted phosphoprotein 1 affect mechanistic target of rapamycin cell signaling in ewes. Biology of Reproduction, $v$. 85, p. 1094-1107, 2011.

BOWEN, J. A.; BAZER, F. W.; BURGHARDT, R. C. Spatial and temporal analyses of integrin and Muc-1 expression in porcine uterine epithelium and trophectoderm in vitro. Biology of Reproduction, v. 56, p. 409-415,1997.

BRIDGES, G. A.; MUSSARD, M. L.; BURKE, C. R.; DAY, M. L. Influence of the length of proestrus on fertility and endocrine function in female cattle. Animal Reproduction Science, v. 117, p. 208-215, 2010.

BRIDGES, G. A.; MUSSARD, M. L.; PATE, J. L.; OTT, T. L.; HANSEN, T. R.; DAY, M. L. Impact of preovulatory estradiol concentrations on conceptus development and uterine gene expression. Animal Reproduction Science, v. 133, p. 16-26, 2012.

CARTER, F.; FORDE, N.; DUFFY, P.; WADE, M.; FAIR, T.; CROWE, M. A.; EVANS, A. C. O.; KENNY, D. A.; ROCHE, J. F.; LONERGAN, P. Effect of increasing progesterone concentration from Day 3 of pregnancy on subsequent embryo survival and development in beef heifers. Reproduction, Fertility and Development, v. 20, p. 368-375, 2008.

CURTIS, S. W.; WASHBURN, T.; SEWALL, C.; DIAUGUSTINE, R.; LINDZEY, J.; COUSE, J. F.; KORACH, K. S. Physiological coupling of growth factor and steroid receptor signaling pathways: estrogen receptor knockout mice lack estrogen-like response to epidermal growth factor. Proceedings of the National Academy of Sciences, v. 93, p. 12626-12630, 1996.

DISKIN M. G.; SREENAN J. M. Fertilization and embryonic mortality rates in beef heifers after artificial insemination. Journal of Reproduction and Fertility. v. 59, p. 463-8, 1980.

DUPONT, S.; KRUST, A.; GANSMULLER, A.; DIERICH, A.; CHAMBON, P.; MARK, $M$. Effect of single and compound knockouts of estrogen receptors alpha (ERalpha) and beta (ERbeta) on mouse reproductive phenotypes. Development, v. 127, p. 4277-4291, 2000.

FILARDO, E. J.; QUINN, J. A.; BLAND, K. I.; FRACKELTON JR, A. R. Estrogeninduced activation of Erk-1 and Erk-2 requires the $G$ protein-coupled receptor homolog, GPR30, and occurs via trans-activation of the epidermal growth factor receptor through release of HB-EGF. Molecular Endocrinology, v. 14, p. 16491660, 2000. 
FORDE, N.; SPENCER, T. E.; BAZER, F. W.; SONG, G.; ROCHE, J. F.; LONERGAN, P. Effect of pregnancy and progesterone concentration on expression of genes encoding for transporters or secreted proteins in the bovine endometrium. Physiological Genomics, v. 41, p. 53-62, 2010.

FRANÇA, M. R.; MESQUITA, F. S.; LOPES, E.; PUGLIESI, G.; VAN HOECK, V.; CHIARATTI, M. R.; MEMBRIVE, C. B.; PAPA, P. C.; BINELLI, M. Modulation of periovulatory endocrine profiles in beef cows: consequences for endometrial glucose transporters and uterine fluid glucose levels. Domestic Animal Endocrinology, v. 50, p. 83-90, 2015.

GARBARINO, E. J.; HERNANDEZ, J. A.; SHEARER, J. K.; RISCO, C. A.; THATCHER, W. W. Effect of lameness on ovarian activity in postpartum Holstein cows. Journal of Dairy Science, v. 87, p. 4123-4131, 2004.

GELLERSEN, B.; FERNANDES, M. S.; BROSENS, J. J. Non-genomic progesterone actions in female reproduction. Human Reproduction Update, v. 15, p. 119-138, 2009.

HALL, J. M.; COUSE, J. F.; KORACH, K. S. The multifaceted mechanisms of estradiol and estrogen receptor signaling. Journal of Biological Chemistry, v. 276, p. 36869-36872, 2001.

HIROI, H.; INOUE, S.; WATANABE, T.; GOTO, W.; ORIMO, A.; MOMOEDA, M.; TSUTSUMI, O.; TAKETANI, Y.; MURAMATSU, M. Differential immunolocalization of estrogen receptor alpha and beta in rat ovary and uterus. Journal of Molecular Endocrinology, v. 22, p. 37-44, 1999.

HORWITZ, K. B.; MCGUIRE, W. L. Nuclear mechanisms of estrogen action: effects of estradiol and anti-estrogens on estrogen receptors and nuclear receptor processing. Journal of Biological Chemistry, v. 253, p. 8185-8191, 1978.

ING, N. H.; FRANCIS, H.; MCDONNELL, J. J.; AMANN, J. F.; ROBERTS, R. M. Progesterone induction of the uterine milk proteins: major secretory proteins of sheep endometrium. Biology of Reproduction, v. 41, p. 643-654, 1989.

JABLONSKI, E. M.; MCCONNELL, N. A.; HUGHES, F. M.; HUET-HUDSON, Y. M. Estrogen regulation of aquaporins in the mouse uterus: potential roles in uterine water movement. Biology of Reproduction, v. 69, p. 1481-1487, 2003.

KIMMINS, S.; MACLAREN, L. A. Oestrous cycle and pregnancy effects on the distribution of oestrogen and progesterone receptors in bovine endometrium.

Placenta, v. 22, p. 742-748, 2001.

KLEIN-HITPASS, L.; RYFFEL, G. U.; HEITLINGER, E.; CATO, A. C. B. A 13 bp palindrome is a functional estrogen responsive element and interacts specifically with estrogen receptor. Nucleic Acids Research, v. 16, p. 647-663, 1988.

KUIPER, G. G. J. M.; CARLSSON, B. O.; GRANDIEN, K. A. J.; ENMARK, E.; HAGGBLAD, J.; NILSSON, S.; GUSTAFSSON, J. Comparison of the ligand binding 
specificity and transcript tissue distribution of estrogen receptors $\alpha$ and $\beta$.

Endocrinology, v. 138, p. 863-870, 1997.

KURITA, T.; YOUNG, P.; BRODY, J. R.; LYDON, J. P.; O’MALLEY, B. W.; CUNHA, G. R. Stromal Progesterone Receptors Mediate the Inhibitory Effects of Progesterone on Estrogen-Induced Uterine Epithelial Cell Deoxyribonucleic Acid Synthesis 1.

Endocrinology, v. 139, p. 4708-4713, 1998.

LEDGARD, A. M.; MEIER, S.; PETERSON, A. J. Evaluation of the uterine environment early in pregnancy establishment to characterise cows with a potentially superior ability to support conceptus survival. Reproduction, Fertility and Development, v. 23, p. 737-747, 2011.

LEVAY, P. Y.; VILJOEN, M. Lactoferrin: a general review. Haematologica, v, 80, p. 252-267, 1995.

LUCIANO, A. M.; CORBANI, D.; LODDE, V.; TESSARO, I.; FRANCIOSI, F.; PELUSO, J. J.; MODINA, S. Expression of progesterone receptor membrane component-1 in bovine reproductive system during estrous cycle. European Journal of Histochemistry, v. 55, p. 145-150, 2011.

LÖSEL, R. M.; BESONG, D.; PELUSO, J. J.; WEHLING, M. Progesterone receptor membrane component 1 -many tasks for a versatile protein. Steroids, v. 73, p. 929934, 2008.

MCMASTER, M. T.; TENG, C. T.; DEY, S. K.; ANDREWS, G. K. Lactoferrin in the mouse uterus: analyses of the preimplantation period and regulation by ovarian steroids. Molecular Endocrinology, v. 6, p. 101-111, 1992.

MENEGHETTI, M.; SÁ FILHO, O. G.; PERES, R. F. G.; LAMB, G. C.; VASCONCELOS, J. L. M. Fixed-time artificial insemination with estradiol and progesterone for Bos indicus cows I: Basis for development of protocols.

Theriogenology, v. 72, p. 179-189, 2009.

MESQUITA, F. S.; PUGLIESI, G.; SCOLARI, S. C.; FRANÇA, M. R.; RAMOS, R. S.; OLIVEIRA, M.; PAPA, P. C.; BRESSAN, F. F.; MEIRELLES, F. V.; SILVA, L. A. Manipulation of the periovulatory sex steroidal milieu affects endometrial but not luteal gene expression in early diestrus Nelore cows. Theriogenology, v. 81, p. 861869, 2014.

MILGROM, E.; THI, L.; ATGER, M.; BAULIEU, E. E.Mechanisms regulating the concentration and the conformation of progesterone receptor (s) in the uterus.

Journal of Biological Chemistry, v. 248, p. 6366-6374, 1973.

MITKO, K.; ULBRICH, S. E.; WENIGERKIND, H.; SINOWATZ, F.; BLUM, H.; WOLF, E.; BAUERSACHS, S. Dynamic changes in messenger RNA profiles of bovine endometrium during the oestrous cycle. Reproduction, v. 135, p. 225-240, 2008.

MOFFATT, J.; BAZER, F. W.; HANSEN, P. J.; CHUN, P. W.; ROBERTS, R. M. Purification, secretion and immunocytochemical localization of the uterine milk 
MOFFATT, J.; BAZER, F. W.; HANSEN, P. J.; CHUN, P. W.; ROBERTS, R. M. Purification, secretion and immunocytochemical localization of the uterine milk proteins, major progesterone-induced proteins in uterine secretions of the sheep. Biology of Reproduction, v. 36, p. 419-430, 1987.

MOTE, P. A.; ARNETT-MANSFIELD, R. L.; GAVA, N.; DEFAZIO, A.; MULACJERICEVIC, B.; CONNEELY, O. M.; CLARKE, C. L. Overlapping and distinct expression of progesterone receptors $A$ and $B$ in mouse uterus and mammary gland during the estrous cycle. Endocrinology, v. 147, p. 5503-5512, 2006.

MULAC-JERICEVIC, B.; CONNEELY, O. M. Reproductive tissue selective actions of progesterone receptors. Reproduction, v. 128, p. 139-146, 2004.

NISWENDER, G. D.; JUENGEL, J. L.; SILVA, P. J.; ROLLYSON, M. K.; MCINTUSH, E.W. Mechanisms controlling the function and life span of the corpus luteum.

Physiological Reviews, v. 80, p. 1-29, 2000.

OKUMU, L. A.; FORDE, N.; FAHEY, A. G.; FITZPATRICK, E.; ROCHE, J. F.; CROWE, M. A.; LONERGAN, P. The effect of elevated progesterone and pregnancy status on mRNA expression and localisation of progesterone and oestrogen receptors in the bovine uterus. Reproduction, v. 140, p. 143-153, 2010.

PAECH, K.; WEBB, P.; KUIPER, G. G. J. M.; NILSSON, S.; GUSTAFSSON, J. -Å.; KUSHNER, P. J.; SCANLAN, T. S. Differential ligand activation of estrogen receptors ER $\alpha$ and ER $\beta$ at AP1 sites. Science, v. 277, p. 1508-1510, 1997.

PELLEGRINI, C.; GORI, I.; ACHTARI, C.; HORNUNG, D.; CHARDONNENS, E.; WUNDER, D.; FICHE, M.; CANNY, G. O. The expression of estrogen receptors as well as GREB1, c-MYC, and cyclin D1, estrogen-regulated genes implicated in proliferation, is increased in peritoneal endometriosis. Fertility and Sterility, v. 98, p. 1200-1208, 2012.

PERES, R. F. G.; JÚNIOR, I. C.; SÁ FILHO, O. G.; NOGUEIRA, G. D. P.; VASCONCELOS, J. L. M. Strategies to improve fertility in Bos indicus postpubertal heifers and nonlactating cows submitted to fixed-time artificial insemination.

Theriogenology, v. 72, p. 681-689, 2009.

PERRY, G. A.; SMITH, M. F.; LUCY, M. C.; GREEN, J. A.; PARKS, T. E.; MACNEIL, M. D.; ROBERTS, A. J.; GEARY, T. W. Relationship between follicle size at insemination and pregnancy success. Proceedings of the National Academy of Sciences U S A, v. 102, p. 5268-5273, 2005.

PFAFFL, M. W. A new mathematical model for relative quantification in real-time RTPCR. Nucleic Acids Research, v. 29, p. 2003-2007, 2001.

PIETRAS, R. J.; SZEGO, C. M. Endometrial cell calcium and oestrogen action. Nature, v. 253, p. 357-359, 1975.

PUGLIESI, G.; SCOLARI, S. C.; MESQUITA, F. S.; MATURANA FILHO, M.; ARAÚJO, E. R.; CARDOSO, D.; SALES, J. N.; MARTIN, I.; SÁ FILHO, M.; BERTAN, C. M. Impact of Probing the Reproductive Tract During Early Pregnancy on Fertility of Beef Cows. Reproduction in Domestic Animals, v. 49, p. 35-39, 2014. 
RAMOS, R. D. S.; MESQUITA, F. S.; D'ALEXANDRI, F. L.; GONELLA-DIAZA, A. M.; PAPA, P. D. C.; BINELLI, M. Regulation of the polyamine metabolic pathway in the endometrium of cows during early diestrus. Molecular Reproduction and Development, v. 81, p. 584-594, 2014.

RAMOS, R. S.; OLIVEIRA, M. L.; IZAGUIRRY, A. P.; VARGAS, L. M.; SOARES, M. B.; MESQUITA, F. S.; SANTOS, F. W.; BINELLI, M. The periovulatory endocrine milieu affects the uterine redox environment in beef cows. Reproductive Biology and Endocrinology, v. 39, p. 1-10, 2015.

ROBINSON, R. S.; MANN, G. E.; LAMMING, G. E.; WATHES, D. C. Expression of oxytocin, oestrogen and progesterone receptors in uterine biopsy samples throughout the oestrous cycle and early pregnancy in cows. Reproduction, v. 122, p. 965-979, 2001.

SATTERFIELD, M. C.; BAZER, F. W.; SPENCER, T. E. Progesterone regulation of preimplantation conceptus growth and galectin 15 (LGALS15) in the ovine uterus. Biology of Reproduction, v. 75, p. 289-296, 2006.

SHIMIZU, T.; KREBS, S.; BAUERSACHS, S.; BLUM, H.; WOLF, E.; MIYAMOTO, A. Actions and interactions of progesterone and estrogen on transcriptome profiles of the bovine endometrium. Physiological Genomics, v. 42, p. 290-300, 2010.

SIDDIQUI, M. A. R.; GASTAL, E. L.; GASTAL, M. O.; ALMAMUN, M.; BEG, M. A.; GINTHER, O. J. Relationship of vascular perfusion of the wall of the preovulatory follicle to in vitro fertilisation and embryo development in heifers. Reproduction, v. 137, p. 689-697, 2009.

SMIT, A. F. A.; HUBLEY, R.; GREEN, P. 1996-2010. RepeatMasker Open-3.0. See http://www. repeatmasker. org.

SPENCER, T. E.; BAZER, F. W. Temporal and spatial alterations in uterine estrogen receptor and progesterone receptor gene expression during the estrous cycle and early pregnancy in the ewe. Biology of Reproduction, v. 53, p. 1527-1543, 1995.

SPENCER, T. E.; GRAY, A.; JOHNSON, G. A.; TAYLOR, K. M.; GERTLER, A.; GOOTWINE, E.; OTT, T. L.; BAZER, F. W. Effects of recombinant ovine interferon tau, placental lactogen, and growth hormone on the ovine uterus. Biology of Reproduction, v. 61, p. 1409-1418, 1999.

SPENCER, T. E.; BAZER, F. W. Biology of progesterone action during pregnancy recognition and maintenance of pregnancy. Frontiers in Bioscience: A Journal and Virtual Library, v. 7, p. 879-1898, 2002.

SPENCER, T. E.; JOHNSON, G. A.; BURGHARDT, R. C.; BAZER, F. W. Progesterone and placental hormone actions on the uterus: insights from domestic animals. Biology of Reproduction, v. 71, p. 2-10, 2004. 
SPENCER, T. E.; JOHNSON, G. A.; BAZER, F. W.; BURGHARDT, R. C. Fetalmaternal interactions during the establishment of pregnancy in ruminants. Society of Reproduction and Fertility Supplement, v. 64, p. 379-396, 2007.

STEWART, M. D.; JOHNSON, G. A.; GRAY, C. A.; BURGHARDT, R. C.; SCHULER, L. A.; JOYCE, M. M.; BAZER, F. W.; SPENCER, T. E. Prolactin receptor and uterine milk protein expression in the ovine endometrium during the estrous cycle and pregnancy. Biology of Reproduction, v. 62, p. 1779-1789, 2000.

SURVEYOR, G. A.; GENDLER, S. J.; PEMBERTON, L.; DAS, S. K.; CHAKRABORTY, I.; JULIAN, J.; PIMENTAL, R. A.; WEGNER, C. C.; DEY, S. K.; CARSON, D. D. Expression and steroid hormonal control of Muc-1 in the mouse uterus. Endocrinology, v. 136, p. 3639-3647, 1995.

TENG, C. T. Regulation of lactoferrin gene expression by estrogen and epidermal growth factor. Cell Biochemistry and Biophysics, v. 31, p. 49-64, 1999.

ULBRICH, S. E.; KETTLER, A.; EINSPANIER, R. Expression and localization of estrogen receptor $\alpha$, estrogen receptor $\beta$ and progesterone receptor in the bovine oviduct in vivo and in vitro. The Journal of Steroid Biochemistry and Molecular Biology, v. 84, p. 279-289, 2003.

ULBRICH, S. E.; FROHLICH, T.; SCHULKE, K.; ENGLBERGER, E.; WALDSCHMITT, N.; ARNOLD, G. J.; REICHENBACH, H. -D.; REICHENBACH, M.; WOLF, E.; MEYER, H. H. D. Evidence for estrogen-dependent uterine serpin (SERPINA14) expression during estrus in the bovine endometrial glandular epithelium and lumen. Biology of Reproduction, v. 81, p. 795-805, 2009.

VANDESOMPELE, J.; DE PRETER, K.; PATTYN, F.; POPPE, B.; VAN ROY, N.; DE PAEPE, A.; SPELEMAN, F. Accurate normalization of real-time quantitative RT-PCR data by geometric averaging of multiple internal control genes. Genome Biology, v. 7, p. 1-12, 2002.

VASCONCELOS, J. L. M.; SARTORI, R.; OLIVEIRA, H. N.; GUENTHER, J. G.; WILTBANK, M. C. Reduction in size of the ovulatory follicle reduces subsequent luteal size and pregnancy rate. Theriogenology, v. 56, p. 307-314, 2001.

WANG, H.; MASIRONI, B.; ERIKSSON, H.; SAHLIN, L. A comparative study of estrogen receptors $\alpha$ and $\beta$ in the rat uterus. Biology of Reproduction, v. 61, p. 955-964, 1999.

ZHU, C.; JIANG, Z.; BAZER, F.W.; JOHNSON, G. A.; BURGHARDT, R. C.; WU, G. Aquaporins in the female reproductive system of mammals. Frontiers in Bioscience (Landmark edition) v. 20, p. 838-871, 2014. 